GEOLOGY, STREAMFLOW, AND WATER CHEMISTRY OF

THE TALUFOFO STREAM BASIN, SAIPAN, NORTHERN MARIANA ISLANDS

U.S. GEOLOGICAL SURVEY

Water-Resources Investigations Report 95-4183

Prepared in cooperation with the

COMMONWEALTH OF THE NORTHERN MARIANA ISLANDS

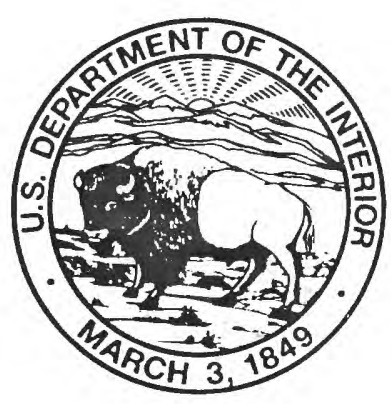




\section{GEOLOGY, STREAMFLOW, AND WATER CHEMISTRY OF}

THE TALUFOFO STREAM BASIN, SAIPAN, NORTHERN MARIANA ISLANDS

By Scot K. Izuka and Charles J. Ewart, III

U.S. GEOLOGICAL SURVEY

Water-Resources Investigations Report 95-4183

Prepared in cooperation with the

COMMONWEALTH OF THE NORTHERN MARIANA ISLANDS

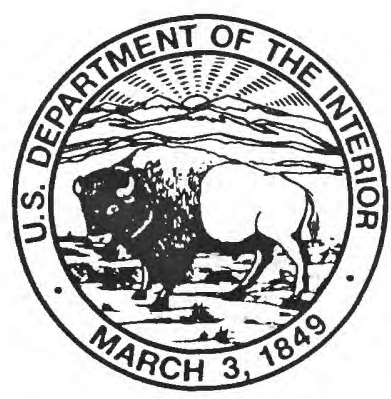

Honolulu, Hawaii

1995 


\section{CONTENTS}

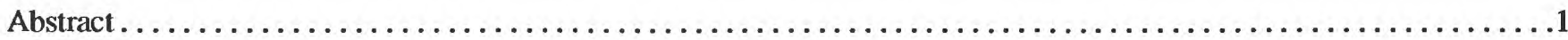

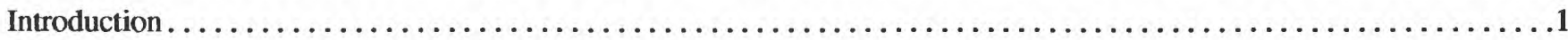

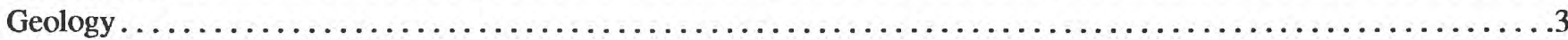

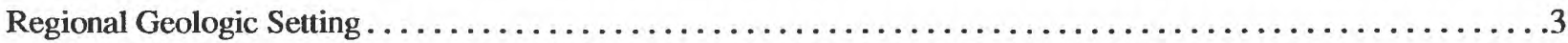

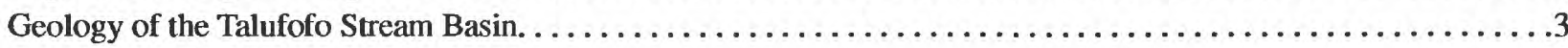

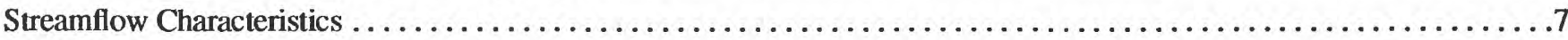

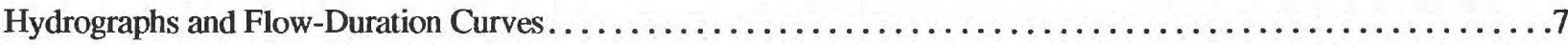

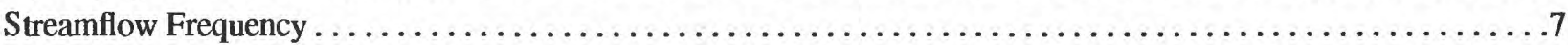

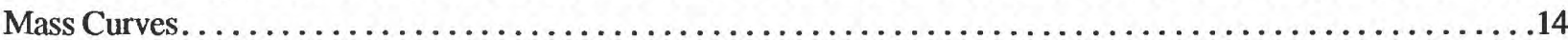

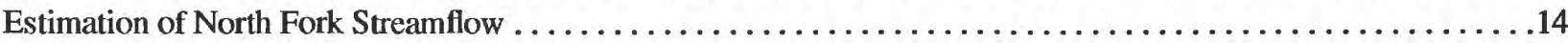

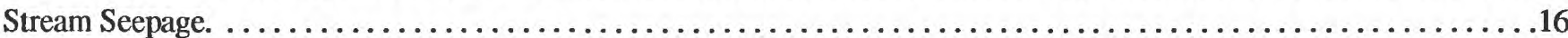

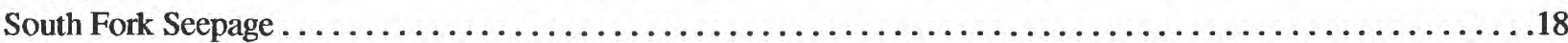

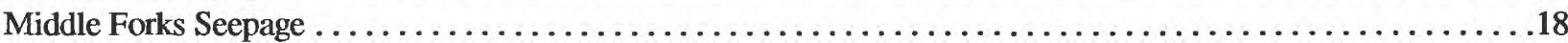

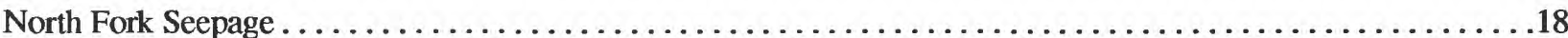

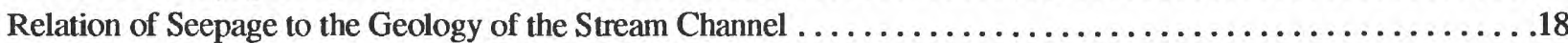

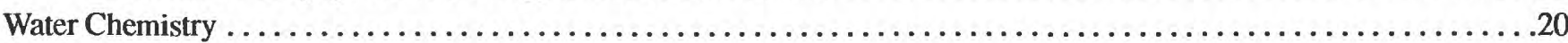

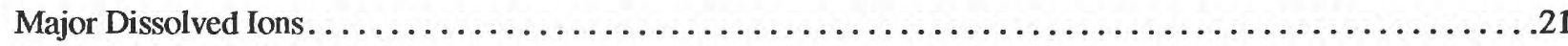

Trace Metal Analysis . . . . . . . . . . . . . . . . . . . . . . . . . . . . . . . . . . . . . 22

Possible Effects of Ground-Water Pumpage on Streamflow. . . . . . . . . . . . . . . . . . . . . . . . . . . . . . 24

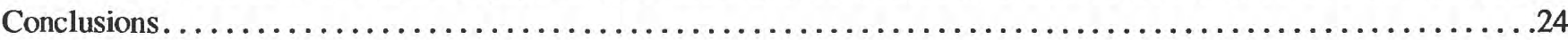

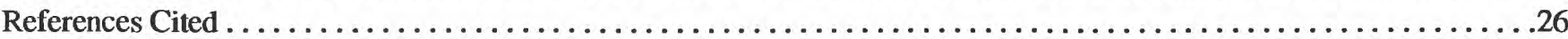

\section{FIGURES}

1-3. Maps showing;

1. Saipan and location of Talufofo Stream Basin . . . . . . . . . . . . . . . . . . . . . . . . . .

2. Gages and seepage-run measuring sites, Talufofo Stream Basin, Saipan $\ldots \ldots \ldots \ldots \ldots \ldots \ldots \ldots \ldots \ldots \ldots \ldots \ldots \ldots \ldots$

3. Generalized geology of the Talufofo Stream area, Saipan. . . . . . . . . . . . . . . . . . . . . . . 5

4-6. Graphs showing:

4. Monthly rainfall at the Communication Center in Kagman, approximately 2.5 mi southeast of the Talufofo Stream Basin, and monthly mean streamflow at the South Fork and Middle Fork gaging stations on Talufofo Stream, Saipan . . . . . . . . . . . . . . . . . . . . .

5. Flow-duration curves for the period of record (April 1971 through March 1986) for the South Fork gaging station (16801000) and concurrent period of record (April 1971 through March 1980) for the South Fork gaging station and Middle Fork gaging station (16801500), Talufofo Stream, Saipan . . . . . . 9

6. Mass curve of discharge at the; $A$, South Fork gage (16801000) and; $B$, Middle Fork gage (16801500)

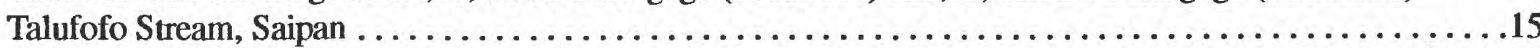

7. Profile and geology along channel of the South Fork and North Fork of Talufofo Stream, Saipan...........19

8. Pie charts showing proportions, based on milliequivalent units, of major dissolved ions in water sampled in June 1990 from Talufofo Stream, Saipan . . . . . . . . . . . . . . . . . . . . . . . . . . .

9. Schematic diagram of possible relationships between ground water and streamflow before and after pumping of wells in the Talufofo Stream area, Saipan. . . . . . . . . . . . . . . . . . . . 


\title{
Geology, Streamflow, and Water Chemistry of the Talufofo Stream Basin, Saipan, Northern Mariana Islands
}

\author{
By Scot K. Izuka and Charles J. Ewart, III
}

\section{Abstract}

A study of the geology, streamflow, and water chemistry of Talufofo Stream Basin, Saipan, Commonwealth of the Northern Mariana Islands, was undertaken to determine the flow characteristics of Talufofo Stream and the relation to the geology of the drainage basin. The Commonwealth government is exploring the feasibility of using water from Talufofo Stream to supplement Saipan's stressed municipal water supply.

Streamflow records from gaging stations on the principal forks of Talufofo Stream indicate that peak streamflows and long-term average flow are higher at the South Fork gaging station than at the Middle Fork gaging station because the drainage area of the South Fork gaging station is larger, but persistent base flow from ground-water discharge during dry weather is greater in the Middle Fork gaging station. The sum of the average flows at the Middle Fork and South Fork gaging stations, plus an estimate of the average flow at a point in the lower reaches of the North Fork, is about $2.96 \mathrm{cu}$ bic feet per second or 1.91 million gallons per day. Although this average represents the theoretical maximum long-term draft rate possible from the Talufofo Stream Basin if an adequate reservoir can be built, the actual amount of surface water available will be less because of evaporation, leaks, induced infiltration, and reservoir-design constraints.

Base-flow characteristics, such as stream seepage and spring discharge, are related to geology of the basin. Base flow in the Talufofo Stream Basin originates as discharge from springs near the base of limestones located in the headwaters of Talufofo
Stream, flows over low-permeability volcanic rocks in the middle reaches, and seeps back into the high-permeability limestones in the lower reaches.

Water sampled from Talufofo Stream during base flow had high dissolved-calcium concentrations (between 35 and 98 milligrams per liter), characteristic of water from a limestone aquifer. Concentrations of potassium, sodium, and chloride ions in water samples from Talufofo Stream are characteristic of water draining a heavily vegetated basin near the ocean.

The streamflow and water-chemistry data indicate that discharge from springs is in hydraulic connection with the limestone aquifer near the headwaters of the basin. The base flow therefore is subject to stresses placed on the nearby limestone ground-water system. Pumping from wells in the limestones at the headwaters of Talufofo Stream Basin may decrease spring flow in Talufofo Stream.

\section{INTRODUCTION}

Saipan is the largest and most populated island in the Commonwealth of the Northern Mariana Islands (CNMI), a north-south trending island chain in the tropical western Pacific. The island is elongate in the northeast-southwest direction and covers an area of about 48 $\mathrm{mi}^{2}$ (fig. 1). A ridge of limestone runs through the middle of the northern two thirds of the island and forms spectacular cliffs, most of which face east. The highest point on the ridge is Mount Tagpochau which is located in the center of the island. Rainfall on Saipan averages about $81 \mathrm{in} / \mathrm{yr}$ (van der Brug, 1985) but varies by seasons (wet from July to December, dry from January to 


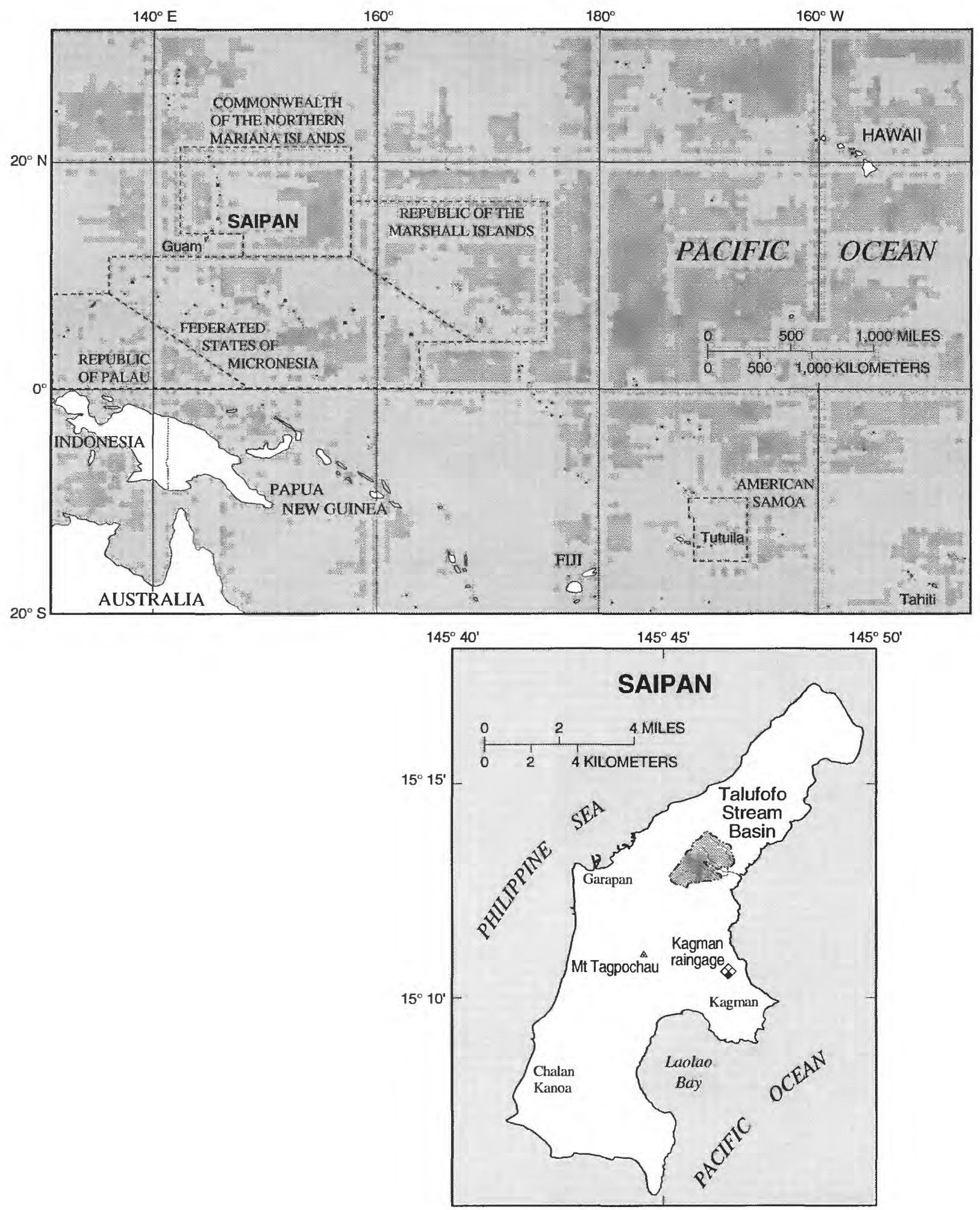

Figure 1. Saipan and location of Talufofo Stream Basin. 
June). Despite the abundant rainfall, few perennial streams exist on Saipan because infiltration into permeable rocks is high (Davis, 1958).

Talufofo Stream is the largest of a system of eastward-flowing streams in the northeast part of the island. The stream drains a triangular area of about $1.6 \mathrm{mi}^{2}$ (fig. 2). It is a dendritic stream with three principal tributaries: the North Fork, Middle Fork, and South Fork. Springs increase discharge into the streams between 400 and $500 \mathrm{ft}$ elevation. The small upper channels are surrounded by grass-covered slopes and coalesce downstream to form the channels of the three principal forks. The lower half of the basin is covered by a dense forest. The three forks come together at a point about $0.4 \mathrm{mi}$ from the coast. Between the confluence and the coast, streamflow is intermittent.

The government of the CNMI is exploring the feasibility of using the water from Talufofo Stream to supplement Saipan's stressed municipal water supply, and entered into a cooperative agreement with the U.S.Geological Survey (USGS) to study flow characteristics of Talufofo Stream and the relation to the geology of the drainage basin. This report describes the flow characteristics of the stream, seepage of water into and out of the ground, identification of the rocks and geologic structures controlling the seepage, and analysis of the major dissolved ions and trace elements in the Talufofo Stream water. Methods used in this study include (1) analysis of records of stream gages on the South Fork and Middle Fork of Talufofo Stream, (2) measurement of the exchange between ground water and the stream, (3) study of the geology of the channel of the stream, and (4) chemical analysis of the stream water.

\section{GEOLOGY}

Geologic information for this study was drawn primarily from the geologic map of Saipan prepared by Cloud and others (1956) and supplemented by field study done in June, 1990. The geologic map of Cloud and others (1956), with minor modifications, was sufficiently detailed for the purposes of this study. The goal of the geologic field work for the present study was to confirm the rock types and geologic structures in the Talufofo Stream Basin and to correlate geology to streamflow characteristics. Thus the geologic field work focused on characterizing rock types from which springs seeped, over which stream water flowed, and into which water infiltrated. The hydrogeologic map of the Talufofo Stream area (fig. 3 ) is simplified from the geologic map of Cloud and others (1956) for the purposes of this study.

\section{Regional Geologic Setting}

A description of rock types and a geologic map of Saipan was produced by Tayama (1938). The geology of Saipan was later more extensively described in a four-part USGS professional paper by Cloud and others (1956). Recent work, completed after the development of plate tectonic theory, has placed Saipan and the other Mariana Islands in a double-arc, convergent plate margin setting (Karig, 1971). Parts of the arc are still active; large-magnitude, deep-focus earthquakes are common and volcanism is still active in the Mariana Islands north of Saipan (Banks and others, 1984).

Saipan was built up from the ocean floor by islandarc volcanoes which typically form cones of pyroclastics and flows of andesitic to dacitic composition. Exposure of the volcanic island to erosion processes reworked the volcanic material to produce clastic sediments, which have been cemented to form sandstones, conglomerates, and breccias of low porosity. Volcanism on Saipan probably ended in the Oligocene, and subsequent marine deposition has produced thick limestones (Cloud and others, 1956). Tectonic uplift of the island has raised these limestones to elevations of over $1,540 \mathrm{ft}$ above sea level (Karig, 1971). Saipan thus consists of an andesitic-dacitic volcanic core overlain by sandstones, conglomerates and breccias, which are in turn capped by limestones. About 95 percent of the surface of the island is mantled with limestone. A fringing reef edges the eastern half of the island, and a barrier reef and lagoon occur on the western side.

\section{Geology of the Talufofo Stream Basin}

Five geologic formations crop out in the area near the Talufofo Stream Basin. The oldest are the Hagman and Densinyama Formations which consist of conglomerates, breccias, sandstones and andesite flows of Eocene age (Cloud and others, 1956). These primarily clastic formations are unconformably overlain by three limestone formations, the Matansa Limestone of Eocene age, the Tagpochau Limestone of Miocene to Pliocene age, and the Mariana Limestone of Pleistocene 


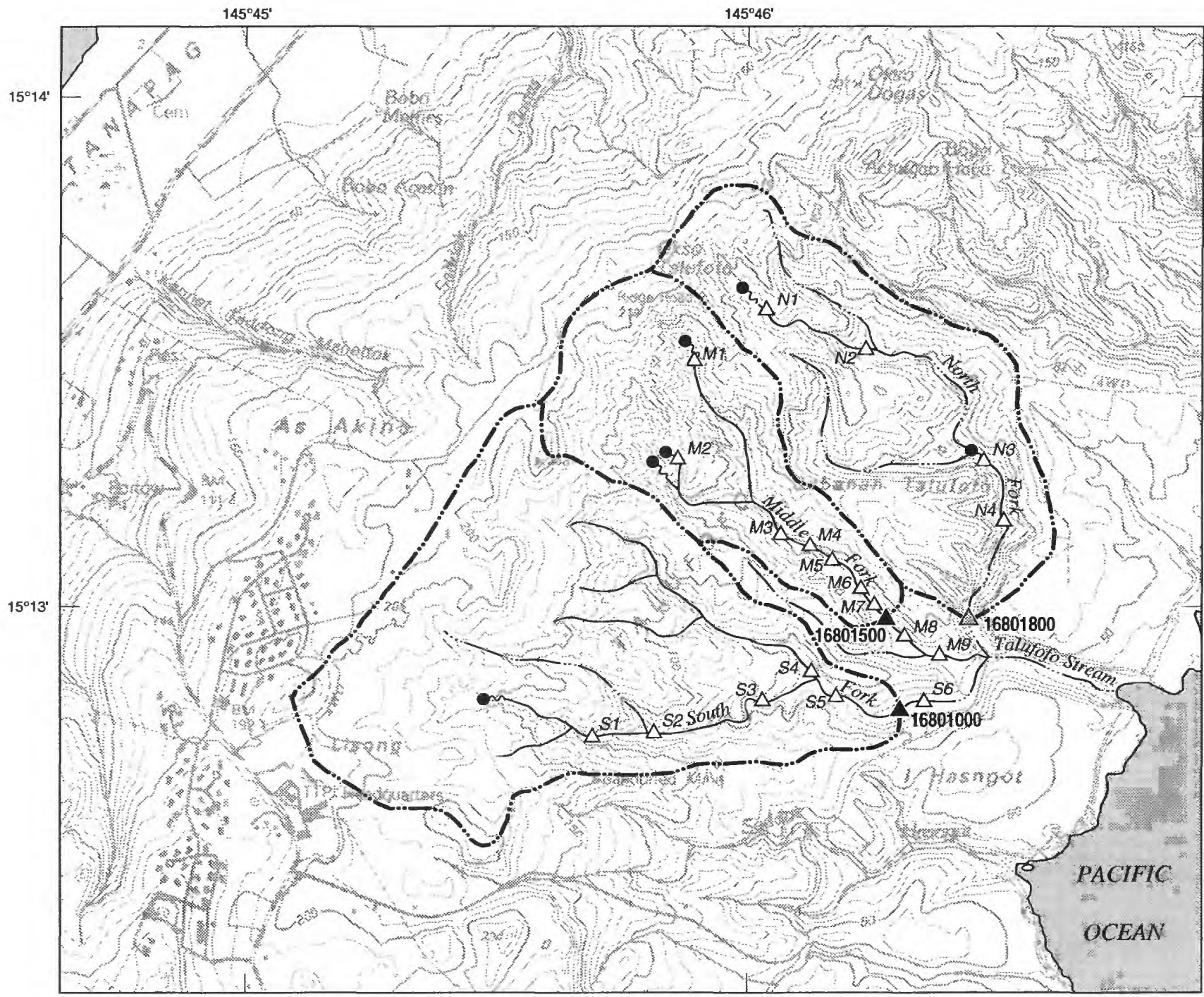

Base from U.S.Geological Survey,

1:25,000, Island of Saipan, 1983

EXPLANATION

\begin{tabular}{|l|ll|}
\hline & \multicolumn{2}{c}{0.25} \\
\hline & 0.25 & 0.5 KILOMETERS \\
Contour interval 10 meters \\
Datum is mean sea level \\
METERS & FEET \\
\hline 50 & $=$ & 164 \\
100 & $=$ & 328 \\
150 & $=$ & 492 \\
200 & $=$ & 656
\end{tabular}
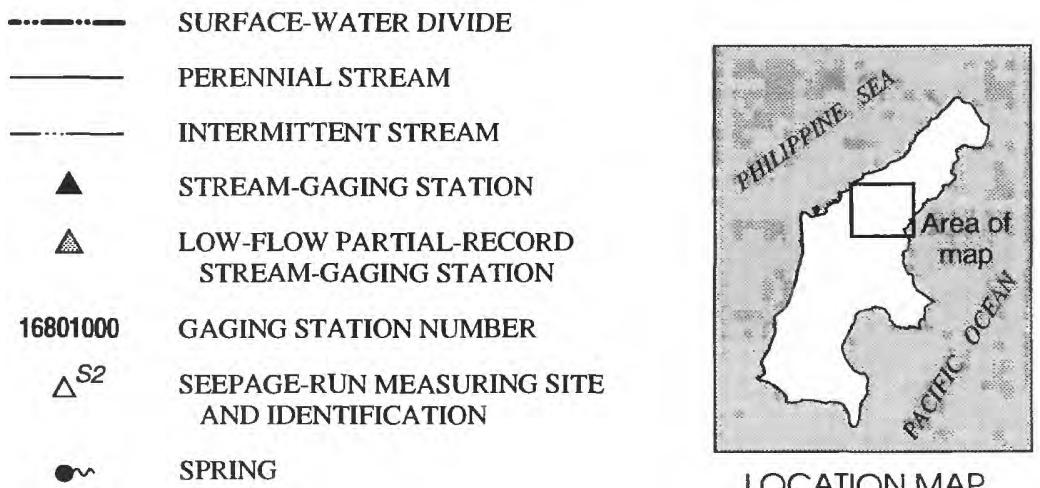

Figure 2. Gages and seepage-run measuring sites,Talufofo Stream Basin, Saipan. 


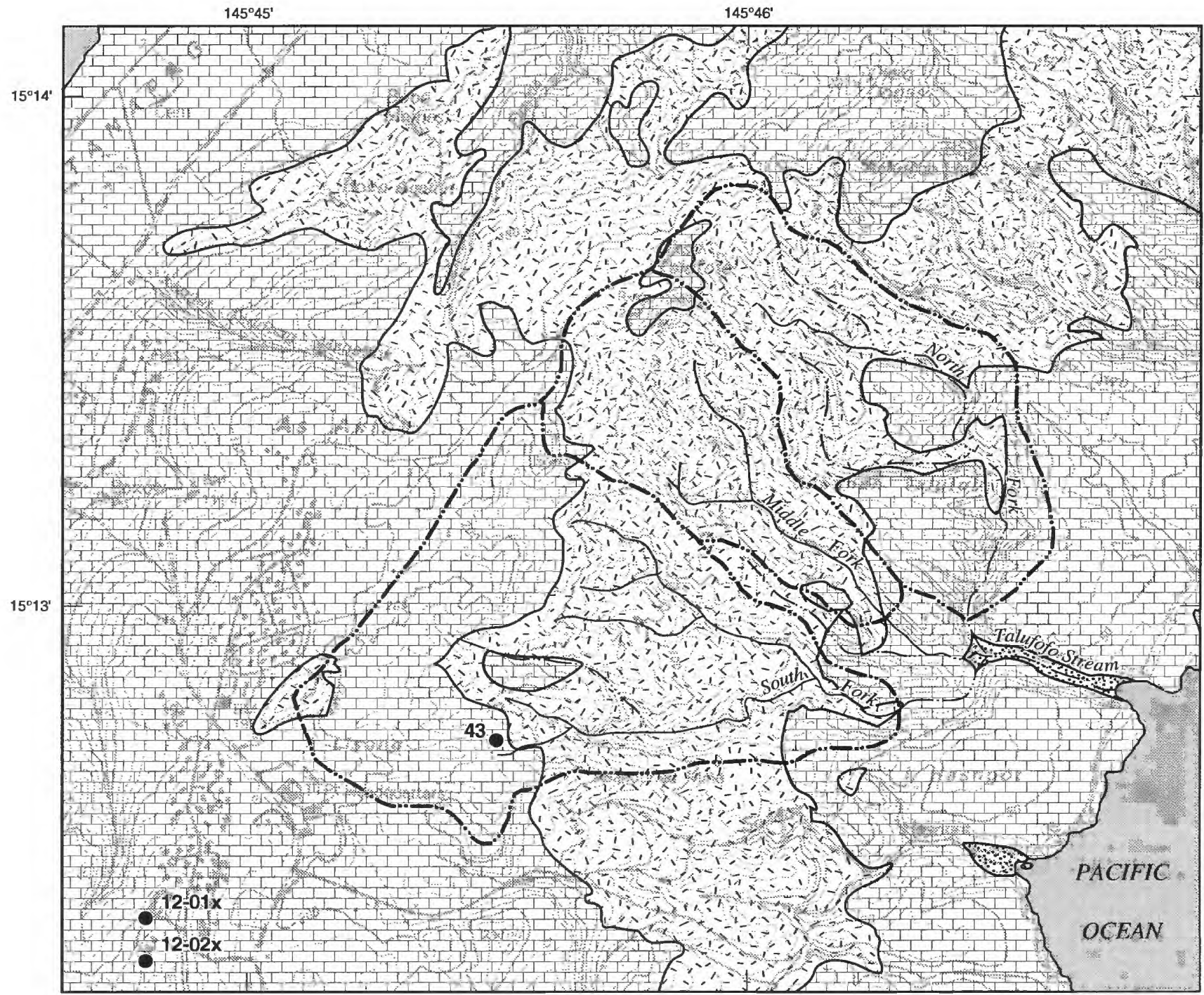

Base from U.S.Geological Survey,

Geology modified from Cloud and others, 1956 $1: 25,000$, Island of Saipan, 1983

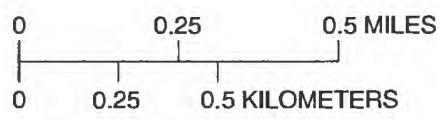

\begin{tabular}{|ccc|}
\hline \multicolumn{2}{|c|}{ Contour interval } & 10 meters \\
Datum is mean sea level \\
METERS & FEET \\
\hline $50=$ & 164 \\
$100=$ & 328 \\
$150=$ & 492 \\
$200=$ & 656 \\
\hline
\end{tabular}

EXPLANATION

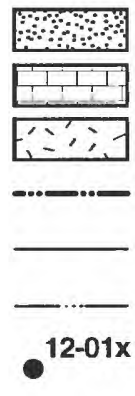

ALLUVIUM

LIMESTONE UNIT

VOLCANIC UNIT

SURFACE-WATER DIVIDE

PERENNIAL STREAM

INTERMITTENT STREAM

WELL AND NUMBER

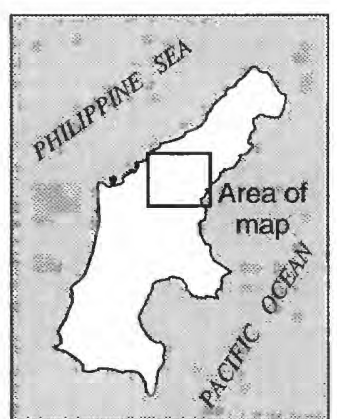

LOCATION MAP

Figure 3. Generalized geology of the Talufofo Stream area, Saipan. 
age (Cloud and others, 1956). Although the Matansa Limestone does not occur within surface-water drainage area of Talufofo Stream, the formation is included in this discussion because outcrops of the limestone near the Talufofo Stream drainage may have an effect ground-water surface-water relations. The lower members of the Matansa Limestone and Tagpochau Limestone include clastic sedimentary rocks similar to those in the Densinyama Formation; the upper members of these formations are impure to pure, white to pink limestone. The Mariana Limestone in the Talufofo area appears as brown-grey fossiliferous limestone, with much of its primary porosity preserved. Porosity of all of the limestone formations are increased by the formation of solution cavities (Davis, 1958).

Because this study is primarily hydrologic, discussions of the geology of the Talufofo Stream area are simplified by grouping rocks that have similar hydrologic properties. The permeability of older volcanic rocks and clastic sedimentary rocks is much less than the permeability of overlying limestones (Davis, 1958). The volcanic and clastic sedimentary formations, including the Hagman and Densinyama Formations (except for the limestone conglomerate facies in the Densinyama Formation) and the lower units of the Tagpochau Formation, are therefore informally grouped in the volcanic unit in this report (table 1). The Mariana Limestone, Matansa Limestone, most of the Tagpochau Limestone, and the limestone conglomerate facies of the Densinyama Formation have moderate to high permeabilities (Davis, 1958). These rocks have been grouped in the limestone unit for this report. The reworked terrace deposits mapped by Cloud and others (1956) which cover parts of the Mariana Limestone are small, surficial deposits that do not contain substantial amounts of ground water and do not come in contact with Talufofo Stream. They are of minor importance to this study and are not differentiated from the rocks over which they lie. Unconsolidated alluvium in the present stream channel and the beach deposits ("emerged limesands" of Cloud and others, 1956) at the mouth of the stream are grouped as a third unit called alluvium in this report. Alluvium consists of angular to rounded boulders, cobbles and pebbles of limestone and volcanic rock as well as sand, silt, clay, and transported soil that partly fills the stream channels. The beach deposits are mostly carbonate sand with some pebbles, cobbles and boulders.

The area drained by Talufofo Stream can be visualized as a window in the overlying limestone cap through which the older volcanic unit is exposed (fig. 3). Because the volcanic unit is much less permeable than the overlying limestones, exposure of the volcanic rocks at the surface plays an important role in the occurrence of streamflow in this area. The volcanic unit comprises 57 percent of the surface rocks of the Talufofo Stream Basin. These rocks are exposed in the central part of the basin and have been incised by numerous tributaries. The remaining 43 percent of the basin is covered by limestone and alluvium. Limestone crops out in the lower basin as well as near the ridge crest that forms the upper boundary of the drainage basin. Alluvium in the stream channels is thin and of small areal extent in most places, except where stream capacity (the ability of the stream to carry sediment) is reduced as water seeps into the ground.

Table 1. Correlation of geohydrologic units in this report with stratigraphic units in Cloud and others, 1956

\begin{tabular}{|c|c|c|}
\hline Stratigraphic units of Cloud and others (1956) & Name in this report & $\begin{array}{l}\text { Lithology and hydrologic } \\
\text { character }\end{array}$ \\
\hline $\begin{array}{l}\text { Alluvium } \\
\text { Emerged limesands }\end{array}$ & Alluvium & $\begin{array}{l}\text { Unconsolidated stream and beach deposits. } \\
\text { Minor importance in study area. }\end{array}$ \\
\hline $\begin{array}{l}\text { Mariana Limestone } \\
\text { Tagpochau Limestone (except Donni Sandstone) } \\
\text { Matansa Limestone } \\
\text { Limestone conglomerate facies of Densinyama } \\
\text { Formation }\end{array}$ & Limestone unit & $\begin{array}{l}\text { Pure to impure limestones. } \\
\text { High primary and secondary porosity, high } \\
\text { permeability }\end{array}$ \\
\hline $\begin{array}{l}\text { Donni Sandstone } \\
\text { Densinyama Formation (except limestone con- } \\
\text { glomerate facies) } \\
\text { Hagman Formation }\end{array}$ & Volcanic unit & $\begin{array}{l}\text { Pyroclastic material, lava flows, sandstones } \\
\text { and conglomerates derived from volcanic } \\
\text { rocks. } \\
\text { Low permeability. }\end{array}$ \\
\hline
\end{tabular}




\section{STREAMFLOW CHARACTERISTICS}

Streamflow characteristics were studied through analysis of stream-gage records which extend through wet and dry seasons over several years. The USGS currently operates one streamflow-gaging station, 16801000, in the Talufofo Stream Basin (fig. 2). The gaging station, located on the South Fork of the stream, was established in October, 1968, but was moved $0.2 \mathrm{mi}$ upstream in March 1971. Because streamflows at the two locations are not equivalent, only the record after March 1971 is used in the analyses in this report. Stream-gage data from the South Fork and Middle Fork before October 1, 1988, are published in the USGS water resources data annual reports (for example, Chinn and others, 1987).

A second gaging station, 16801500, installed on the Middle Fork, was operated from March 1968 through June 1980, and February through September 1982 (fig. 2). No continuous record exists for the North Fork, nor for the channel below the confluence of the three forks of Talufofo Stream. The USGS established low-flow, partial-record stations in the North Fork and main channel in 1968, but the stations were discontinued in 1971 because the channels were dry, except during storms. This report uses the North Fork partialrecord station (16801800) as an index station to estimate North Fork discharge. Statistical analyses on stream-gage records are based on years with complete records only. Years with incomplete data are eliminated from the analyses because data may be biased toward a wet-season or dry-season flow.

\section{Hydrographs and Flow-Duration Curves}

Comparison of hydrographs plotted from data collected during the concurrent period of record for the South Fork gaging station (16801000) and Middle Fork gaging station (16801500) provide a comparison of the flow characteristics of the two drainage basins. Comparison of the hydrograph of monthly discharge with total monthly rainfall from 1971 through 1980 shows the correlation between streamflow and rainfall (fig. 4). During high-flow periods, discharges on the South Fork were higher than on the Middle Fork primarily because the drainage area of the South Fork is 1.7 times the drainage area of the Middle Fork. During dry periods, however, a higher base flow persisted in the Middle Fork than in the South Fork.
Flow-duration curves from daily mean discharges were computed for the concurrent period of record of the Middle and South Forks (April 1, 1971 through March 31, 1980) and for the entire period of record of the South Fork gaging station (April 1, 1971 through March 1986; fig. 5). The flow-duration curves show that high flows were of greater magnitude at the South Fork gaging station than at the Middle Fork gaging station, but base flow was higher at the Middle Fork gaging station than at the South Fork gaging station. The flow-duration curve of the South Fork gaging station is almost a straight line, which is characteristic of a stream with a very small ground-water component. Flow at the South Fork gaging station diminished to zero on several days in April, May, and June, 1984. In contrast, the flow-duration curve of the Middle Fork is steep on the left and flattens toward the right. The flattening of the flow-duration curve indicates that even during dry periods, a discharge of about $0.1 \mathrm{ft}^{3} / \mathrm{s}$ persisted at the Middle Fork gaging station. The stream did not stop flowing at the gaging station during the period of record. The lowest instantaneous discharge recorded at the site was $0.5 \mathrm{ft}^{3} / \mathrm{s}$ on July 5 and 6,1977 .

In summary, flow-duration curves and hydrographs indicate that base flow in Talufofo Stream was higher at the Middle Fork gaging station than at the South Fork gaging station, whereas discharge during rainy periods was higher at the South Fork gaging station. Higher peak discharges at the South Fork gaging station can be attributed to a larger drainage area, but the higher persistent base flow at the Middle Fork gaging station was due to a greater ground-water component.

\section{Streamflow Frequency}

Another streamflow characteristic important to reservoir design is the frequency and magnitude of extremely high- and extremely low-flows. The high-flow frequency analysis determines the chance or probability that extremely high and extremely low flows will occur in a given year. The probabilities that a flow will occur in the future is determined by fitting the historical data to a log-Pearson type III probability function (an explanation of the log-Pearson type III function is given in Chow, 1964b). The accuracy of the estimated chances is limited by the amount of historical data available, that is, the period of record of the gaging station. The longer the period of record, the more accurately the frequency 


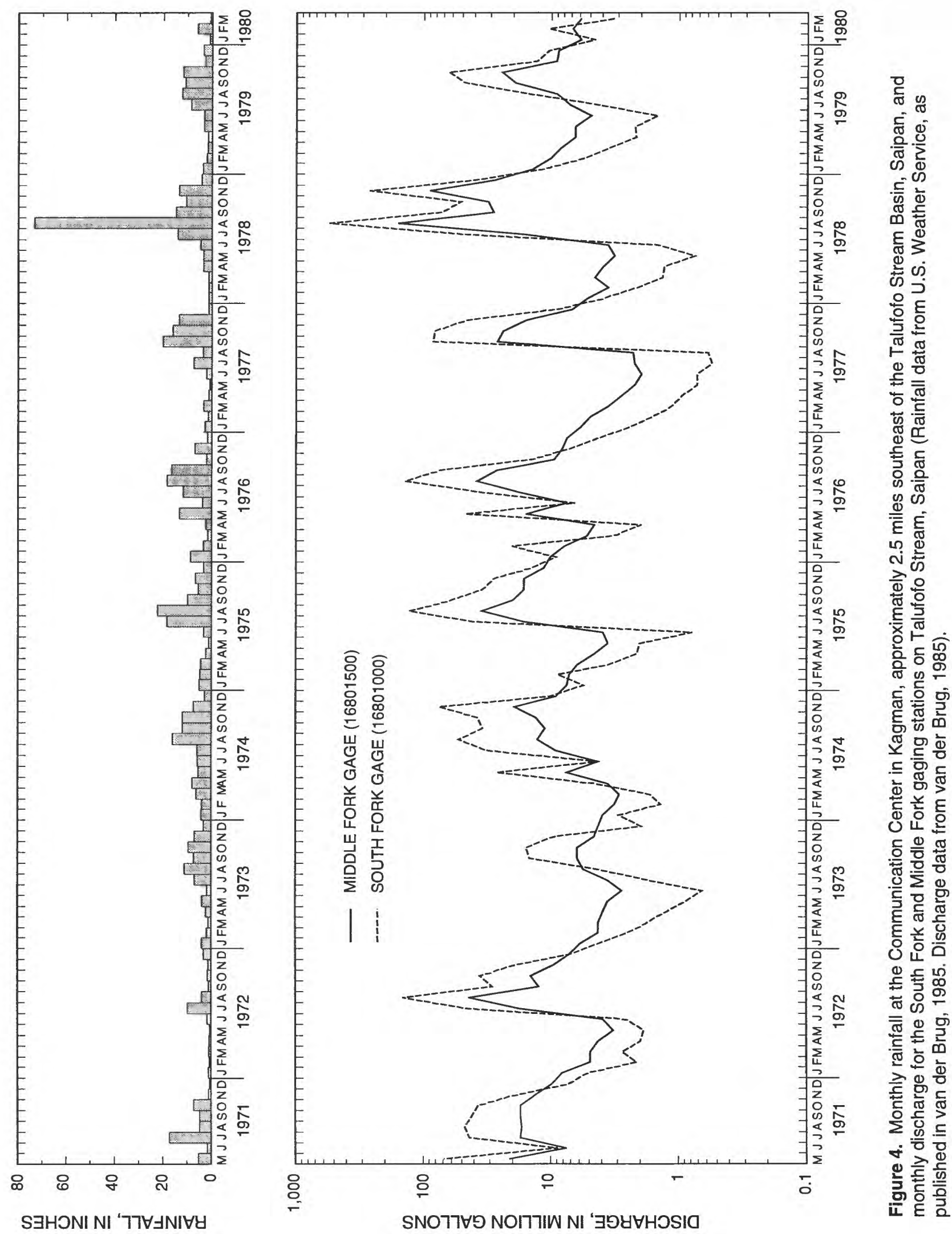




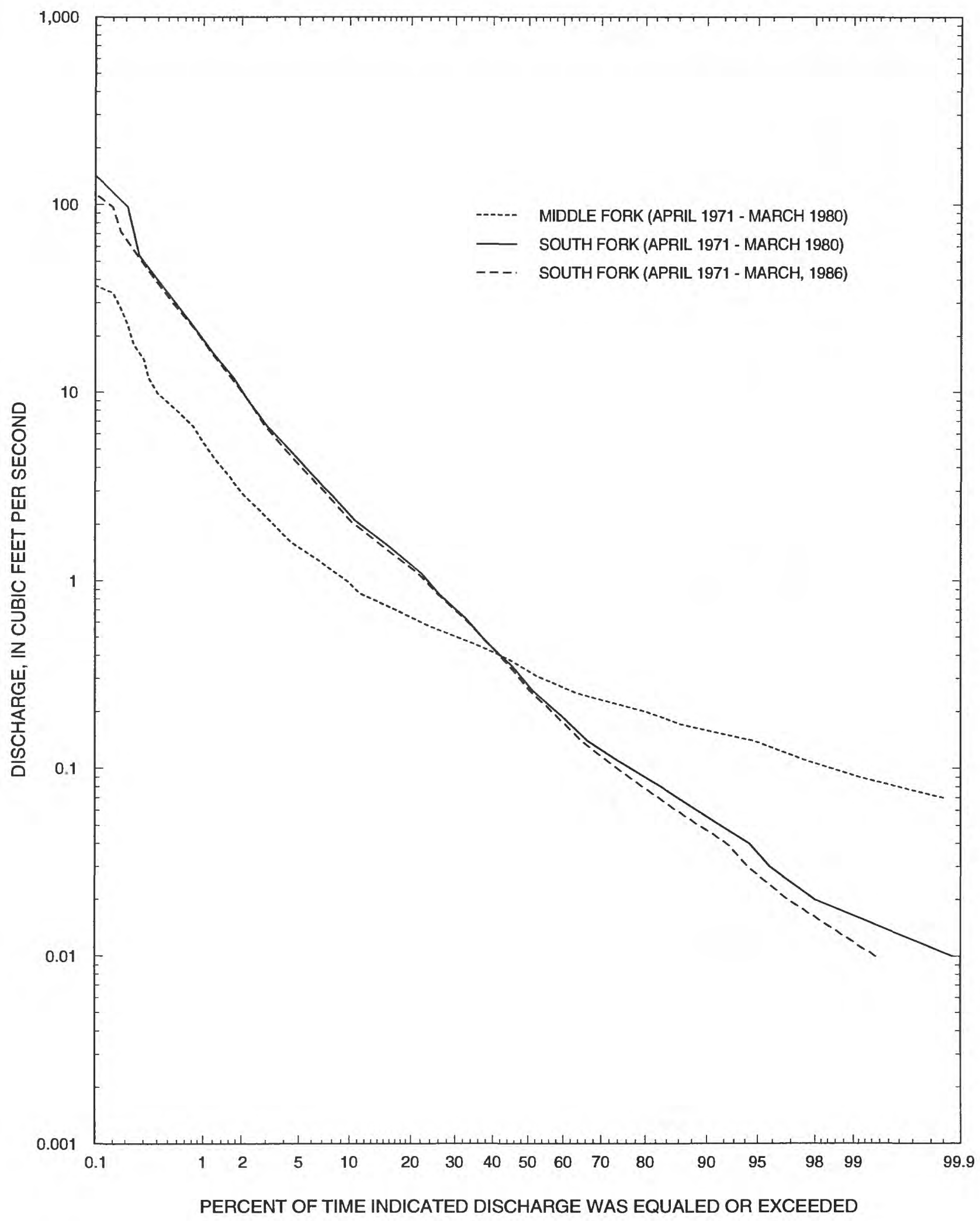

Figure 5. Flow-duration curves for the period of record (April 1971 through March 1986) for the South Fork gage (16801000) and concurrent period of record (April 1971 to March 1980) for the South Fork gage and Middle Fork gage (16801500), Talufofo Stream Basin, Saipan. 
analysis will be able to predict the chance of rare occurrences such as extremely high floods or extremely low flows. Frequency analyses in this study are based on the entire periods of record for the South Fork and Middle Fork gaging stations. For the low-flow analyses, only complete years, beginning with the month of December (the start of the dry season), were used to avoid splitting complete low-flow periods. For the high-flow analyses, only complete years, beginning with the month of July (the start of the wet season) are used to avoid splitting complete high-flow periods.
High-flow frequency analysis.--The highest flows at the South Fork gaging station, averaged over 1, 7, 30, $60,90,183$ and 365 consecutive days within a year are shown in table 2. Periods of highest recorded flows at the South Fork gaging station occurred in the year July 1978 to June 1979 (table 2), when an average flow of $8.70 \mathrm{ft}^{3} / \mathrm{s}$ persisted for 183 days (which is approximately equal to the length of a wet season). The frequency analysis indicates that such a wet season is rare, however, because the chance that a given wet season in the future will have an average flow of equal or greater magnitude at the South Fork gaging station is less than

Table 2. Highest mean flows for periods of 1 to 365 consecutive days for years beginning in July and ending in June at the South Fork gaging station (16801000), Talufofo Stream, Saipan.

\begin{tabular}{lccccccc}
\hline \multirow{2}{*}{ Year } & \multicolumn{7}{c}{ Highest mean flow, in cubic feet per second, for a period of } \\
\cline { 2 - 7 } & $\mathbf{1}$ day & $\mathbf{7}$ days & $\mathbf{3 0}$ days & $\mathbf{6 0}$ days & $\mathbf{9 0}$ days & $\mathbf{1 8 3}$ days & 365 days \\
\hline $1971-72$ & 17.0 & 5.81 & 3.95 & 2.59 & 2.64 & 1.64 & 0.89 \\
$1972-73$ & 83.0 & 23.0 & 9.33 & 5.26 & 4.17 & 2.38 & 1.24 \\
$1973-74$ & 26.0 & 5.41 & 1.51 & 0.86 & 0.70 & 0.42 & 0.38 \\
$1974-75$ & 44.0 & 12.4 & 4.64 & 3.13 & 3.07 & 2.04 & 1.12 \\
$1975-76$ & 43.0 & 14.2 & 7.76 & 5.48 & 4.19 & 2.63 & 1.63 \\
$1976-77$ & 100 & 23.4 & 7.56 & 5.48 & 4.38 & 2.32 & 1.20 \\
$1977-78$ & 59.0 & 16.7 & 5.75 & 4.72 & 3.67 & 1.92 & 0.99 \\
$1978-79$ & 303 & 92.9 & 28.8 & 16.4 & 14.7 & 8.70 & 4.46 \\
$1979-80$ & 18.0 & 8.84 & 4.34 & 2.84 & 2.16 & 1.32 & 0.73 \\
$1980-81$ & 119 & 23.1 & 8.11 & 5.06 & 5.08 & 2.91 & 1.51 \\
$1981-82$ & 54.0 & 17.6 & 9.76 & 5.81 & 4.46 & 3.69 & 2.00 \\
$1982-83$ & 91.0 & 27.0 & 8.90 & 5.22 & 4.04 & 2.25 & 1.16 \\
$1983-84$ & 2.70 & 1.32 & 0.87 & 0.56 & 0.44 & 0.27 & 0.17 \\
$1984-85$ & 31.0 & 8.89 & 3.94 & 3.39 & 3.00 & 1.76 & 1.07 \\
$1985-86$ & 71.0 & 13.4 & 6.18 & 4.26 & 3.41 & 2.23 & 1.36 \\
\hline
\end{tabular}

Table 3. Discharge averaged over specified number of consecutive days, and the chance that such an average discharge will be equaled or exceeded in a given year at the South Fork gaging station (16801000), Talufofo Stream, Saipan

[Discharge in cubic feet per second; statistics based on stream records from 1971 to 1986 for years beginning in July and ending in June]

\begin{tabular}{ccccccc}
\hline \multirow{2}{*}{ Consecutive days } & \multicolumn{9}{c}{ Chance, in percent } \\
\cline { 2 - 7 } & $\mathbf{5 0}$ & $\mathbf{2 0}$ & $\mathbf{1 0}$ & $\mathbf{4}$ & $\mathbf{2}$ & $\mathbf{1}$ \\
\hline 1 & 54.7 & 115 & 155 & 200 & 229 & 254 \\
7 & 14.4 & 29.9 & 41.7 & 57.7 & 70.0 & 82.4 \\
30 & 6.05 & 11.3 & 14.9 & 19.6 & 23.0 & 26.2 \\
60 & 4.17 & 7.30 & 9.16 & 11.2 & 12.4 & 13.5 \\
90 & 3.51 & 6.18 & 7.78 & 9.50 & 10.6 & 11.5 \\
183 & 2.12 & 3.76 & 4.74 & 5.81 & 6.48 & 7.06 \\
365 & 1.18 & 1.99 & 2.48 & 3.00 & 3.34 & 3.63 \\
\hline
\end{tabular}


1 percent (table 3$)$. There is a much greater chance $(50$ percent) that the average flow in a given wet-season will be at least $2.12 \mathrm{ft}^{3} / \mathrm{s}$. In other words, about half the years in the future are expected to have a mean wet-season flow of at least $2.12 \mathrm{ft}^{3} / \mathrm{s}$ at the South Fork gaging station. The highest 1-day mean streamflow on the South Fork record, $303 \mathrm{ft}^{3} / \mathrm{s}$, occurred on August 12, 1978.

The highest recorded wet-season flow at the Middle Fork gaging station, $3.01 \mathrm{ft}^{3} / \mathrm{s}$, occurred in the year
July 1968 to June 1969 , and again in the year July 1978 to June 1979 (table 4). The chance that a given wet season will have an average flow of at least this magnitude is between 4 and 10 percent (table 5). Average wet-season streamflow has a 50 percent chance of being at least $0.90 \mathrm{ft}^{3} / \mathrm{s}$ at the Middle Fork gaging station.

Table 4. Highest mean flows for periods of 1 to 365 consecutive days in years beginning in July and ending in June at the Middle Fork gaging station (16801500), Talufofo Stream, Saipan

\begin{tabular}{|c|c|c|c|c|c|c|c|}
\hline \multirow[b]{2}{*}{ Year } & \multicolumn{7}{|c|}{ Highest mean flow, in cubic feet per second, for a period of } \\
\hline & 1 day & 7 day & 30 days & 60 days & 90 days & 183 days & 365 days \\
\hline $1968-69$ & 64.0 & 12.8 & 7.10 & 4.38 & 4.77 & 3.01 & 1.68 \\
\hline $1969-70$ & 49.0 & 9.43 & 2.55 & 1.56 & 1.28 & 1.05 & 0.67 \\
\hline $1970-71$ & 6.70 & 2.40 & 1.18 & 0.98 & 0.81 & 0.60 & 0.58 \\
\hline $1971-72$ & 4.00 & 1.49 & 1.10 & 0.93 & 0.95 & 0.77 & 0.51 \\
\hline $1972-73$ & 26.0 & 6.97 & 2.80 & 1.68 & 1.37 & 0.89 & 0.55 \\
\hline $1973-74$ & 5.40 & 1.06 & 0.40 & 0.32 & 0.30 & 0.26 & 0.24 \\
\hline $1974-75$ & 9.00 & 2.25 & 1.13 & 0.83 & 0.79 & 0.63 & 0.46 \\
\hline $1975-76$ & 8.60 & 3.32 & 2.07 & 1.58 & 1.32 & 1.00 & 0.70 \\
\hline $1976-77$ & 22.0 & 5.95 & 2.29 & 1.66 & 1.43 & 0.91 & 0.54 \\
\hline $1977-78$ & 16.0 & 4.72 & 1.64 & 1.38 & 1.13 & 0.69 & 0.43 \\
\hline $1978-79$ & 84.0 & 24.9 & 8.38 & 5.02 & 4.77 & 3.01 & 1.70 \\
\hline $1979-80$ & 8.10 & 3.29 & 1.63 & 1.13 & 0.92 & 0.67 & 0.46 \\
\hline $1981-82$ & 15.0 & 8.71 & 3.93 & 2.50 & 1.69 & 1.51 & 0.95 \\
\hline
\end{tabular}

Note: Data for $1980-81$ was incomplete and is not included

Table 5. Discharge averaged over specified number of consecutive days, and the chance that such an average discharge will be equaled or exceeded in a given year at the site of the Middle Fork gaging station(16801500), Talufofo Stream, Saipan

[Discharge in cubic feet per second; statistics based on stream records from 1968 to 1982 for years beginning in July and ending in June, excluding the incomplete record of the year June 1980 to July 1981]

\begin{tabular}{ccccccc}
\hline $\begin{array}{c}\text { consecutive } \\
\text { days }\end{array}$ & $\mathbf{5 0}$ & $\mathbf{2 0}$ & $\mathbf{1 0}$ & $\mathbf{4}$ & $\mathbf{2}$ & $\mathbf{1}$ \\
\cline { 2 - 7 } & $\mathbf{5 0}$ & 34.3 & 56.2 & 98.4 & 144 & 205 \\
\hline 1 & 4.5 & 9.83 & 14.8 & 23.3 & 31.2 & 40.9 \\
7 & 4.56 & 4.09 & 5.83 & 8.51 & 10.9 & 13.5 \\
30 & 2.07 & 2.68 & 3.61 & 4.93 & 6.00 & 7.13 \\
60 & 1.49 & 2.36 & 3.36 & 4.98 & 6.48 & 8.27 \\
90 & 1.25 & 1.60 & 2.22 & 3.19 & 4.08 & 5.11 \\
183 & 0.90 & 0.97 & 1.29 & 1.80 & 2.25 & 2.79 \\
365 & 0.60 & & & & &
\end{tabular}


Table 6. Lowest mean flows for periods of 1 to 365 consecutive days in years beginning in December and ending in November at the South Fork gaging station (16801000), Talufofo Stream, Saipan.

\begin{tabular}{cccccccc}
\hline & \multicolumn{7}{c}{ Lowest mean flow, in cubic feet per second, for a period of } \\
\cline { 2 - 7 } Year & $\mathbf{1 ~ d a y}$ & $\mathbf{7}$ days & $\mathbf{3 0}$ days & $\mathbf{6 0}$ days & $\mathbf{9 0}$ days & $\mathbf{1 8 3}$ days & $\mathbf{3 6 5}$ days \\
\hline $1971-72$ & 0.06 & 0.07 & 0.09 & 0.10 & 0.11 & 0.12 & 1.26 \\
$1972-73$ & 0.01 & 0.01 & 0.03 & 0.03 & 0.04 & 0.07 & 0.27 \\
$1973-74$ & 0.01 & 0.02 & 0.04 & 0.07 & 0.08 & 0.33 & 1.16 \\
$1974-75$ & 0.01 & 0.01 & 0.03 & 0.07 & 0.08 & 0.17 & 1.38 \\
$1975-76$ & 0.08 & 0.09 & 0.10 & 0.13 & 0.17 & 0.64 & 1.54 \\
$1976-77$ & 0.00 & 0.00 & 0.01 & 0.03 & 0.03 & 0.04 & 0.95 \\
$1977-78$ & 0.02 & 0.03 & 0.04 & 0.04 & 0.05 & 0.09 & 4.26 \\
$1978-79$ & 0.04 & 0.05 & 0.07 & 0.09 & 0.09 & 0.16 & 0.89 \\
$1979-80$ & 0.03 & 0.04 & 0.06 & 0.07 & 0.07 & 0.14 & 1.44 \\
$1980-81$ & 0.02 & 0.03 & 0.03 & 0.04 & 0.06 & 0.13 & 1.71 \\
$1981-82$ & 0.05 & 0.05 & 0.07 & 0.10 & 0.14 & 0.32 & 1.58 \\
$1982-83$ & 0.01 & 0.01 & 0.01 & 0.02 & 0.02 & 0.04 & 0.18 \\
$1983-84$ & 0.00 & 0.00 & 0.00 & 0.01 & 0.02 & 0.04 & 0.89 \\
$1984-85$ & 0.02 & 0.03 & 0.05 & 0.05 & 0.07 & 0.30 & 1.17 \\
\hline
\end{tabular}

Table 7. Discharge averaged over specified number of consecutive days, and the chance that such an average discharge will not be exceeded at the South Fork gaging station (16801000), Talufofo Stream, Saipan

[Discharge in cubic feet per second; Statistics based on stream records from 1971 to 1985 years beginning in December and ending in November]

\begin{tabular}{|c|c|c|c|c|c|c|c|c|}
\hline \multirow{2}{*}{$\begin{array}{c}\text { Consecutive } \\
\text { days }\end{array}$} & \multicolumn{8}{|c|}{ Chance, in percent } \\
\hline & 90 & 80 & 50 & 20 & 10 & 5 & 2 & 1 \\
\hline 1 & 0.06 & 0.04 & 0.02 & 0.01 & 0.01 & 0.01 & 0.00 & 0.00 \\
\hline 7 & 0.07 & 0.05 & 0.03 & 0.01 & 0.01 & 0.00 & 0.00 & 0.00 \\
\hline 30 & 0.09 & 0.07 & 0.04 & 0.02 & 0.01 & 0.01 & 0.00 & 0.00 \\
\hline 60 & 0.11 & 0.09 & 0.07 & 0.03 & 0.02 & 0.02 & 0.01 & 0.01 \\
\hline 90 & 0.14 & 0.11 & 0.06 & 0.04 & 0.03 & 0.02 & 0.01 & 0.01 \\
\hline 183 & 0.40 & 0.27 & 0.13 & 0.06 & 0.04 & 0.03 & 0.02 & 0.02 \\
\hline 365 & 2.53 & 2.04 & 1.20 & 0.59 & 0.38 & 0.25 & 0.15 & 0.10 \\
\hline
\end{tabular}

Low-flow frequency analysis.--The low-flow frequency analysis is an important consideration in assessing the frequency and severity of droughts. The lowest mean flows at the South Fork gaging station averaged over periods of $1,7,30,60,90,183$, and 365 days within each year are shown in table 6. At the South Fork gaging station, severe dry seasons occurred in the years December 1976 through November 1977, December 1982 through November 1983, and December 1983 through November 1984, when the lowest flows over 183-consecutive days (approximately the length of a dry season) averaged only $0.04 \mathrm{ft}^{3} / \mathrm{s}$. Dry-season flows are not expected to be this low in most years, however. The low-flow frequency analysis indicates that the chance that the average flow over a dry-season will be no more than $0.04 \mathrm{ft}^{3} / \mathrm{s}$ is 10 percent (table 7). There is a 50 percent chance that the average flow in a given dry season will be $0.13 \mathrm{ft}^{3} / \mathrm{s}$ or less. 
The Middle Fork gaging station was not in operation during the severe dry period of 1982-83 that was recorded at the South Fork gaging station, but the Middle Fork gaging station did record the severe dry period in the year December 1976 through November 1977 (table 8). Average dry-season flow was $0.12 \mathrm{ft}^{3} / \mathrm{s}$ during that year. A dry season of this severity has only a 5 to 10 percent chance of recurring at the site of the Middle Fork gaging station in a given year (table 9). There is a 50 percent chance that average streamflow at the Middle Fork gaging station site will not exceed $0.26 \mathrm{ft}^{3} / \mathrm{s}$ over a given dry season.

Table 8. Lowest mean flows for periods of 1 to 365 consecutive days in years beginning in December and ending in November at the Middle Fork gaging station (16801500), Talufofo Stream, Saipan.

\begin{tabular}{cccccccc}
\hline & \multicolumn{7}{c}{ Lowest mean flow, cubic feet per second, for a period of } \\
\cline { 2 - 8 } Year & $\mathbf{1}$ day & $\mathbf{7}$ days & $\mathbf{3 0}$ days & $\mathbf{6 0}$ days & $\mathbf{9 0}$ days & $\mathbf{1 8 3}$ days & $\mathbf{3 6 5}$ days \\
\hline $1968-69$ & 0.10 & 0.13 & 0.15 & 0.18 & 0.20 & 0.23 & 0.56 \\
$1969-70$ & 0.17 & 0.21 & 0.25 & 0.33 & 0.32 & 0.44 & 0.63 \\
$1970-71$ & 0.19 & 0.20 & 0.24 & 0.26 & 0.36 & 0.55 & 0.67 \\
$1971-72$ & 0.13 & 0.14 & 0.16 & 0.18 & 0.19 & 0.22 & 0.58 \\
$1972-73$ & 0.10 & 0.12 & 0.14 & 0.15 & 0.16 & 0.19 & 0.24 \\
$1973-74$ & 0.08 & 0.12 & 0.14 & 0.15 & 0.16 & 0.22 & 0.40 \\
$1974-75$ & 0.12 & 0.12 & 0.18 & 0.19 & 0.20 & 0.27 & 0.62 \\
$1975-76$ & 0.14 & 0.16 & 0.22 & 0.24 & 0.25 & 0.42 & 0.69 \\
$1976-77$ & 0.06 & 0.07 & 0.08 & 0.10 & 0.10 & 0.12 & 0.42 \\
$1977-78$ & 0.13 & 0.14 & 0.16 & 0.16 & 0.17 & 0.20 & 1.50 \\
$1978-79$ & 0.16 & 0.18 & 0.22 & 0.27 & 0.27 & 0.35 & 0.62 \\
\hline
\end{tabular}

Table 9. Discharge averaged over specified number of consecutive days, and the chance that such an average discharge will not be exceeded at the site of the Middle Fork gaging station (16801500), Talufofo Stream, Saipan

[Discharge in cubic feet per second; statistics based on stream records from 1968 to 1971, for years beginning in December and ending in November]

\begin{tabular}{|c|c|c|c|c|c|c|c|c|}
\hline \multirow{2}{*}{$\begin{array}{l}\text { Consecutive } \\
\text { days }\end{array}$} & \multicolumn{8}{|c|}{ Chance, in percent } \\
\hline & 90 & 80 & 50 & 20 & 10 & 5 & 2 & 1 \\
\hline 1 & 0.18 & 0.16 & 0.12 & 0.09 & 0.08 & 0.06 & 0.05 & 0.05 \\
\hline 7 & 0.20 & 0.18 & 0.15 & 0.11 & 0.09 & 0.08 & 0.06 & 0.05 \\
\hline 30 & 0.25 & 0.22 & 0.18 & 0.13 & 0.11 & 0.09 & 0.08 & 0.07 \\
\hline 60 & 0.29 & 0.26 & 0.19 & 0.14 & 0.12 & 0.10 & 0.09 & 0.08 \\
\hline 90 & 0.32 & 0.28 & 0.21 & 0.15 & 0.13 & 0.11 & 0.09 & 0.08 \\
\hline 183 & 0.47 & 0.38 & 0.26 & 0.18 & 0.15 & 0.13 & 0.11 & 0.10 \\
\hline 365 & 1.02 & 0.83 & 0.56 & 0.39 & 0.33 & 0.29 & 0.25 & 0.22 \\
\hline
\end{tabular}




\section{Mass Curves}

The long-term relation between cumulative discharge and time is shown in mass curves from daily mean discharge values for the South and Middle Forks (fig. 6). The slope of a line connecting any two points on a mass curve is the average flow rate between the points: steeper slopes indicate a higher rate of flow than flatter slopes. Average discharge at the South Fork gaging station for the interval between 1971 and 1987 (fig. $6 A)$, was $0.88 \mathrm{Mgal} / \mathrm{d}\left(1.36 \mathrm{ft}^{3} / \mathrm{s}\right)$. The Middle Fork averaged $0.46 \mathrm{Mgal} / \mathrm{d}\left(0.71 \mathrm{ff}^{3} / \mathrm{s}\right)$ between 1968 to 1980 (fig. $6 B$ ). The sinuosity of the Talufofo mass curves indicates the seasonal nature of rainfall, and therefore stream runoff, on Saipan. However, the magnitude of the seasonal differences may vary from one year to the next. For example, the wet season in 1973-74 was of relatively short duration, and the dry season was lengthy. On the other hand, intensive rains in the wet season of 1978-79 resulted in a high volume of discharge.

Mass curves also are used to estimate draft rates and storage requirements of a reservoir built for water supply (Chow, 1964a, Ritter and Engstrom, 1964). Slopes representing various draft rates are plotted in figure 6. If a reservoir had been built at either gaging station and completely filled at the beginning of the mass curve, a draft rate exceeding the average flow into the reservoir would have eventually depleted the reservoir. Thus, the theoretical limit to the rate of prolonged withdrawal is the long-term average flow of the stream. The theoretical maximum volume of water that could have been withdrawn from the South and Middle Forks combined is $1.34 \mathrm{Mgal} / \mathrm{d}\left(2.07 \mathrm{ft}^{3} / \mathrm{s}\right)$, the sum of the average flows in the two streams. The realistic limit, however, will be less than the average flow because of leaks, evaporation, and other factors.

A draft rate less than the average flow could be maintained if the reservoir from which the water is drawn has adequate storage. Mass curves can be used to estimate the minimum reservoir capacity required to sustain a desired draft rate (Chow, 1964a, p. 14-45). For example, to estimate the minimum reservoir size that would have been needed to sustain a draft equal to the average flow at the South Fork gaging station ( 0.88 $\mathrm{Mgal} / \mathrm{d}$ ) during the period of record, the two parallel lines with slopes equal to the draft rate are drawn tangent to the curve above and below the draft rate line. The vertical difference between the upper and lower tangent lines, $970 \mathrm{Mgal}$, is the reservoir capacity that would have been required to provide a continuous draft of $0.88 \mathrm{Mgal} / \mathrm{d}$ for the period of record (1968-80) (fig. $6 A)$. Similarly, to have maintained a draft equal to the average flow at the Middle Fork gaging station over the period of record $(0.46 \mathrm{Mgal} / \mathrm{d})$ would have required a reservoir with a capacity of $460 \mathrm{Mgal}$ (fig. 6 B).

These example calculations discuss situations as they may have occurred in the past, but other draft rates may be applied to the curve to determine required capacities of reservoirs that are yet to be built. As with any predictive computation based on past records, however, a degree of uncertainty exists. This uncertainty increases inversely with the length of the record and directly with how far into the future the prediction extends. Also, the analysis does not account for leaks and evaporation. A more detailed discussion on the use of mass curves may be found in a number of textbooks (for example, Chow, 1964a; Ritter and Engstrom, 1964, Linsley and Franzini, 1972).

\section{Estimation of North Fork Streamflow}

Although no gage records are available for the North Fork of Talufofo Stream, streamflow can be estimated by comparing drainage basin characteristics of a gaged stream with those of the ungaged stream. Previous studies show that several drainage-basin characteristics are significantly correlated to discharge. Thomas and Benson (1970) found that the most important characteristics are drainage basin size and mean annual precipitation. Thomas and Benson (1970) also studied the feasibility of using basin characteristics in multiple regression analysis to estimate discharge at ungaged streams and concluded that high flows are more accurately estimated than low flows.

The drainage basins of the South, Middle and North Forks of Talufofo Stream are in such close proximity that they probably share many characteristics, such as annual precipitation and forest cover. Although their drainage areas and geology differ, average streamflow of the North Fork at the site of the discontinued partial-record station 16801800 (fig. 2) may be estimated by comparison with the gaged South and Middle Forks.

The geology and low-flow characteristics of the North Fork more closely parallel those of the South Fork than those of the Middle Fork, because the Middle 

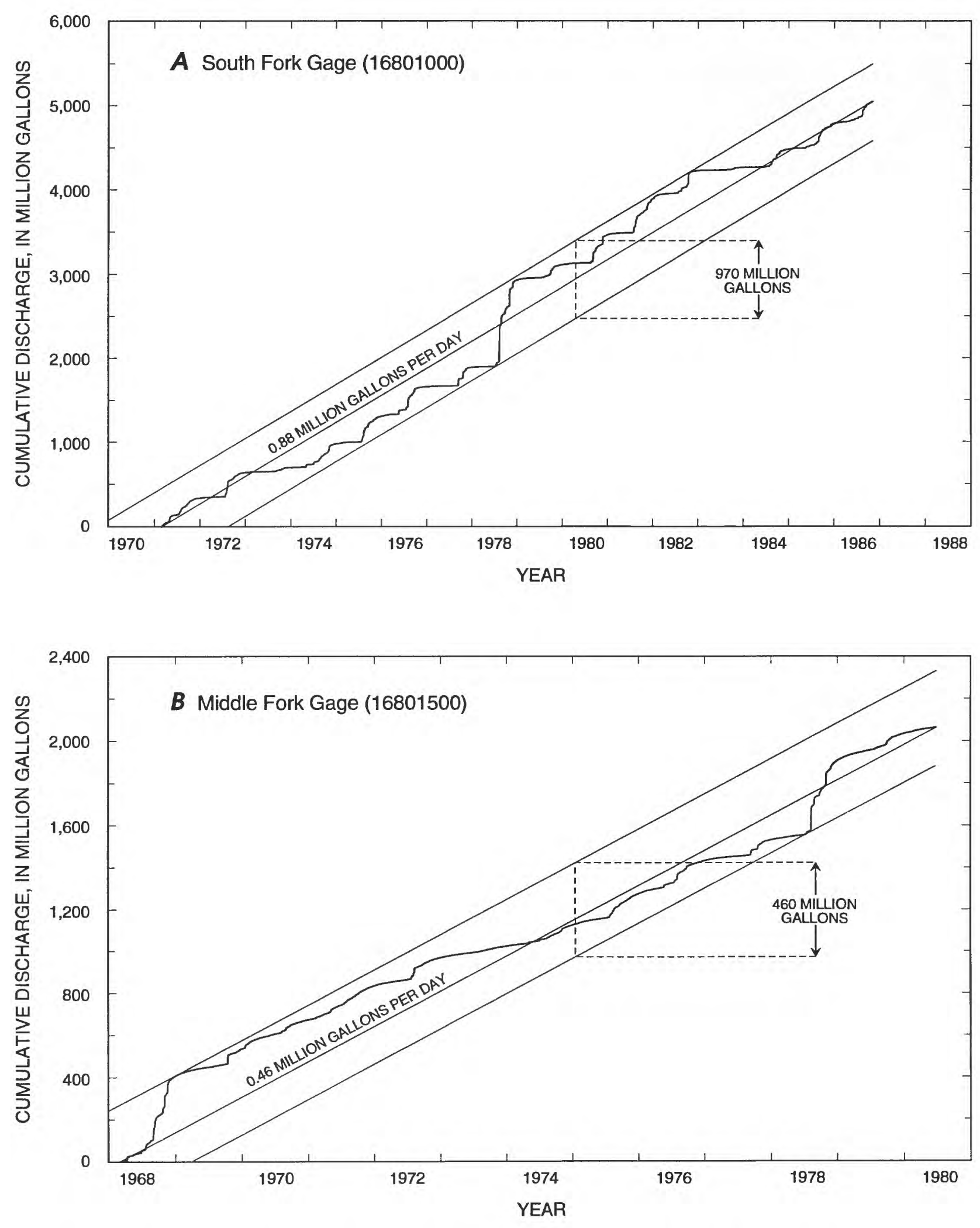

Figure 6. Mass curve of discharge at the; $\boldsymbol{A}$, South Fork gage (16801000) and; $\boldsymbol{B}$, Middle Fork gage (16801500) Talufofo Stream, Saipan. Vertical separation between upper and lower tangent lines gives reservoir capacity ( $A, 970$ million gallons and $B, 460$ million gallons) required for an average draft of 0.88 million gallons per day. 
Fork has a larger ground-water contribution than elsewhere in the Talufofo Stream Basin. For this reason, the streamflow of the South Fork was used to estimate the discharge of the North Fork. Assuming the ratios of average streamflow to drainage area in the South and North Forks are equivalent, average streamflow for the North Fork at partial-record station 16801800 can be estimated by the following equation:

$$
Q_{N F}=\frac{D A_{N F}}{D A_{S F}} \times Q_{S F}
$$

where: $Q_{N F}$ is average streamflow at North Fork partial-record station 16801800 , $D A_{N F}$ is drainage area of North Fork partialrecord station 16801800 ,

$D A_{S F}$ is drainage area of South Fork gaging station 16801000 , and

$Q_{S F}$ is average streamflow at South Fork gaging station 16801800 .

The drainage area of partial-record station 16801800 on the North Fork is $0.45 \mathrm{mi}^{2}$. The South Fork has a drainage area of $0.69 \mathrm{mi}^{2}$ at the site of gaging station 16801000 . Average streamflow recorded between 1971 and 1986 at the South Fork gaging station was $1.36 \mathrm{ft}^{3} / \mathrm{s}$. Substituting these values into equation 1 yields an estimated average streamflow of $0.89 \mathrm{ft}^{3} / \mathrm{s}$ at partial-record station 16801800 . From the summation of the average streamflows of the three forks, the maximum amount of water that can be withdrawn from the Talufofo Basin is $2.96 \mathrm{ft}^{3} / \mathrm{s}$, or $1.91 \mathrm{Mgal} / \mathrm{d}$.

Using a simple ratio of drainage areas to estimate North Fork streamflow assumes basin conditions are essentially the same except for drainage area. Although the drainage basins of North Fork partial-record station 16801800 and South Fork gaging station 16801000 are more similar to each other than to the basin of the Middle Fork gaging station 16801500 , the geology of the North and South Forks differ in two important respects. The reach of the North Fork above partial-record station 16801800 flows over a greater proportion of limestone than does the reach of the South Fork above gaging station 16801000. In addition, the South Fork gaging station 1681000 is located on volcanic rock, whereas the North Fork partial-record station 16801800 is located on permeable limestone. These geologic differences may result in higher infiltration in the North Fork than in the South Fork. The North Fork streamflow may thus be overestimated by equation 1 . The overestimation pri- marily affects the low flows, which constitute only a small part of the total long-term streamflow. Even so, the estimate of North Fork streamflow is probably a maximum.

\section{STREAM SEEPAGE}

Stream seepage, the exchange between surface water and ground water, was studied by seepage runs on each fork of Talufofo Stream. In each seepage run, discharge was measured at selected sites along the channel of the stream and compared. If a downstream site had a higher or lower discharge than an upstream site and there were no tributaries or other sources of surface water between the two sites, the difference in flow was attributed to seepage. The seepage run of this study was conducted in the dry season (June 1990) in order to eliminate the effects of runoff from rainfall. The streamflow that persists during dry weather originates from ground-water discharge and is known as base flow (Langbein and Iseri, 1960).

Streamflow measurements for the seepage runs in this study were made at the end of the 1990 dry season, and therefore represent only dry-weather conditions (table 10). At most sites, streamflow was measured using the 0.6 depth, pygmy current-meter method described by Rantz and others (1982). Accuracy of pygmy-meter measurements is based on field conditions such as evenness of flow, channel morphology and roughness, and volume of flow and can range from excellent $( \pm 2$ percent) to poor (greater than 8 percent). At some sites where streamflow was too low to measure accurately with the current meter, volumetric measurements were made by timing the rate at which the streamflow filled a container of known volume. Volumetric measurements are normally good ( \pm 5 percent) to excellent, but are rarely possible because of the difficulties in capturing all of a stream's flow. At other sites where neither volumetric nor current-meter measurements were possible, a rough estimate of stream velocity was made by timing a floating object through a straight channel reach, taking 85 percent of the measured velocity, and multiplying it by the channel's cross-sectional area to obtain discharge (Rantz and others, 1982). Discharges measured by this method may have a large percent error, but because the magnitudes of the flows measured by this method in this study were $0.01 \mathrm{ft}^{3} / \mathrm{s}$ or less, the actual error in cubic feet per second had little effect on the seepage analyses. 
Table 10. Summary of discharge measurements at selected sites, Talufofo Stream, Saipan

$\left[\mathrm{ft}^{3} / \mathrm{s}\right.$, cubic feet per second; <, less than]

\begin{tabular}{cccccc}
\hline Site number & $\begin{array}{c}\text { Date of } \\
\text { measurement }\end{array}$ & $\begin{array}{c}\text { Method of } \\
\text { measurement }{ }^{2}\end{array}$ & $\begin{array}{c}\text { Accuracy of } \\
\text { measurement }^{3}\end{array}$ & $\begin{array}{c}\text { Streamflow } \\
\left.\text { (ft }^{3} / \mathbf{s}\right)\end{array}$ & $\begin{array}{c}\text { Daily mean flow at } \\
\text { gaging station } \\
\left.\mathbf{1 6 8 0 1 0 0 0 ^ { 4 }} \text { (ft }^{3} / \mathbf{s}\right)\end{array}$ \\
\hline S1 & $6-20-90$ & float speed & poor & 0.01 & 0.06 \\
S2 & $6-13-90$ & volumetric & good & $<0.01$ & 0.06 \\
S3 & $6-13-90$ & current meter & poor & 0.01 & 0.06 \\
S4 & $6-13-90$ & current meter & poor & 0.04 & 0.06 \\
S5 & $6-13-90$ & current meter & fair & 0.04 & 0.06 \\
S6 & $6-13-90$ & float speed & poor & $<0.01$ & 0.06 \\
M1 & $6-08-90$ & current meter & poor & 0.03 & 0.12 \\
M2 & $6-08-90$ & current meter & poor & 0.03 & 0.12 \\
M3 & $6-08-90$ & current meter & fair & 0.27 & 0.12 \\
M4 & $6-11-90$ & current meter & good & 0.24 & 0.10 \\
M5 & $6-11-90$ & current meter & fair & 0.20 & 0.10 \\
M6 & $6-11-90$ & current meter & good & 0.21 & 0.10 \\
M7 & $6-11-90$ & current meter & good & 0.21 & 0.10 \\
M8 & $6-11-90$ & current meter & poor & 0.12 & 0.10 \\
M9 & $6-12-90$ & current meter & fair & 0.12 & 0.08 \\
N1 & $6-15-90$ & volumetric & good & $<0.01$ & 0.05 \\
N2 & $6-15-90$ & current meter & poor & 0.09 & 0.05 \\
N3 & $6-12-90$ & current meter & poor & 0.01 & 0.08 \\
N4 & $6-12-90$ & current meter & fair & 0.03 & 0.08 \\
\hline
\end{tabular}

${ }^{1}$ Site numbers correspond to numbers in figure 2 .

${ }^{2}$ Methods of streamflow measurement include:

current meter - 0.6-depth pygmy current meter method described in Rantz and others (1983),

volumetric - measuring the time needed to fill a known volume with the streamflow,

float speed - measuring surface speed with a floating object and converting to streamflow using methods described in Rantz and others (1983)

${ }^{3}$ Accuracy of measurements: good, \pm 5 percent error, fair, \pm 8 percent error, poor, $>8$ percent error.

${ }^{4}$ Streamflow for gage 16801000 is the daily mean streamflow for the day in which the seepage measurement was made.

Because spring discharge, and thus base flow, in Talufofo Stream Basin varies directly with rainfall (van der Brug, 1985), seepage during the wet season may differ from the patterns of gains and losses described in this study. During the seepage-run measurements, streamflow at the South Fork gaging station varied from 0.05 to $0.12 \mathrm{ft}^{3} / \mathrm{s}$. The flow-duration curve (fig. 5) shows that this range of streamflow was equaled or exceeded 65 to 80 percent of the time during the period of record of the South Fork gaging station (1971 through 1988).

Ideally, streamflow measurements in a seepage run should be made when streamflow conditions are not changing. If the seepage-run measurements are made nearly simultaneously, changes in streamflow with time will have a minor effect on the seepage calculations. Because of the difficult access to some measuring sites on Talufofo Stream, however, it was not possible to make simultaneous measurements. The streamflow measurements for the seepage runs were completed over a span of 13 days between June 8 and 20, 1990 . Part of the uncertainties resulting from time gaps between measurements can be reduced by treating each fork separately, because measurements for any single fork were made over shorter periods. In addition, the comparability of widely spaced seepage-run measurements can be assessed by examining the discharge recorded at the South Fork gaging station during the measurement periods. 


\section{South Fork Seepage}

The seepage-run measurements of the South Fork were made on June 13 and June 20, 1990. Because the mean streamflow at the South Fork gaging station on each of these days was $0.06 \mathrm{ft}^{3} / \mathrm{s}$ (table 10), seepage-run measurements on these days are considered directly comparable. Streamflow in the South Fork was traced to an elevation of about $490 \mathrm{ft}$ where the flow originated from a pool at the base of a $20 \mathrm{ft}$ waterfall (not flowing at the time). The water in the pool seeped from the volcanic unit exposed in the stream channel. Farther downstream, the flow was joined by flow from a southern tributary; their combined flow measured $0.01 \mathrm{ft}^{3} / \mathrm{s}$ (site S1, fig. 2; table 102). The stream continued to flow at this low discharge between S1 and S3. A northern tributary, flowing $0.04 \mathrm{ft}^{3} / \mathrm{s}$ at site $\mathrm{S} 4$ at the time of this study, joined the South Fork upstream from but near site S5. To determine if the stream gained or lost water between sites S3 and S5, the contribution of the tributary was subtracted from the discharge at $\mathbf{S 5}$. The result was an apparent loss of $0.01 \mathrm{ft}^{3} / \mathrm{s}$ between $\mathrm{S} 3$ and $\mathrm{S} 5$. The difference between discharge at site $\mathrm{S} 5$ and the daily mean discharge at the South Fork gaging station indicates that the stream gained about $0.02 \mathrm{ft}^{3} / \mathrm{s}$ water along this reach. In the short reach between sites S5 and the $\mathrm{S} 6$, the flow diminished to less than $0.01 \mathrm{ft}^{3} / \mathrm{s}$.

Except for the small loss between sites S3 and S5, which may not be significant considering the accuracy of the discharge measurements (table 10), the South Fork gained water primarily at three sites: (1) the springs at the headwaters of the stream, (2) the tributary near site S5, and (3) the reach between S5 and the South Fork gaging station. The South Fork loses base flow to seepage between the gaging station and site S6 and flow ceased entirely in a small pool a few feet downstream from site 6 .

\section{Middle Fork Seepage}

Streamflow in the Middle Fork was traced to seeps from the volcanic unit at an elevation of about $400 \mathrm{ft}$. The streamflow in one of the channels leading to the Middle Fork (site M1, fig. 2) issued from several seeps with a combined flow of $0.03 \mathrm{ft}^{3} / \mathrm{s}$. A flow of $0.03 \mathrm{ft}^{3} / \mathrm{s}$ was measured at a southern tributary at approximately the same elevation (site M2, fig. 2). Flow at the confluence of these tributaries (site M3) was $0.27 \mathrm{ft}^{3} / \mathrm{s}$. Com- parison of the sum of streamflows at M1 and M2 $(0.06$ $\left.\mathrm{ft}^{3} / \mathrm{s}\right)$ with the streamflow at M3 $\left(0.27 \mathrm{ft}^{3} / \mathrm{s}\right)$ indicates a gain of $0.21 \mathrm{ft}^{3} / \mathrm{s}$. At site M4, the streamflow was 0.24 $\mathrm{ft}^{3} / \mathrm{s}$, an apparent loss of $0.03 \mathrm{ft}^{3} / \mathrm{s}$, but streamflow at sites M1 to M3 were measured on June 8, 1990, whereas streamflow at sites M4 to M8 were measured on June 11 when the mean streamflow at the South Fork was $0.02 \mathrm{ft}^{3} / \mathrm{s}$ less. Therefore, the apparent loss between M3 and M4 may be less than $0.03 \mathrm{ft}^{3} / \mathrm{s}$. Streamflow decreased between sites M4 and M5 then remained essentially constant to site M7. Streamflow decreased again between sites $\mathrm{M} 7$ and $\mathrm{M} 8$ and remained constant at 0.12 $\mathrm{ft}^{3} / \mathrm{s}$ between sites M8 and M9.

Small differences (less than $0.03 \mathrm{ft}^{3} / \mathrm{s}$ ) in discharge among sites along the reach between sites M3 and M7 may be insignificant considering the accuracy of the measurements. The data do show, however, that the Middle Fork gains significant base flow above M3, changes very little between M3 and M7, but loses significantly between $\mathrm{M} 7$ and M8. All surface flow ceased before the confluence of the Middle Fork with the South and North Forks.

\section{North Fork Seepage}

Base flow in the North Fork was encountered at an elevation of about $430 \mathrm{ft}$, where water seeped from small pools in the volcanic unit. Less than $0.01 \mathrm{ft}^{3} / \mathrm{s}$ was measured at site $\mathrm{N} 1$, about $100 \mathrm{ft}$ downstream from the seeps. Between sites N1 and N2, the stream gained about $0.09 \mathrm{ft}^{3} / \mathrm{s}$. Below N2, surface flow diminished and eventually ceased until it reemerged near site N3. Between site $\mathrm{N} 3$ and $\mathrm{N} 4$, the stream gained water, and below N4, flow ceased in small limestone pools.

\section{Relation of Seepage to the Geology of the Stream Channel}

Base flows in June, 1990, in the South and Middle Forks of Talufofo Stream were continuous from their beginning at springs between 400 and $490 \mathrm{ft}$ elevation to where the flow diminished to zero at about $30 \mathrm{ft}$ elevation (fig. 2). Over this entire reach, both forks of the stream flowed over the volcanic unit (fig. 7). Discharge in each fork increased in the upper reaches but decreased downstream. During the dry season, no surface water flowed in reaches below the $30 \mathrm{ft}$ elevation where the channels of the South and Middle Forks are en- 
A

WEST

EAST

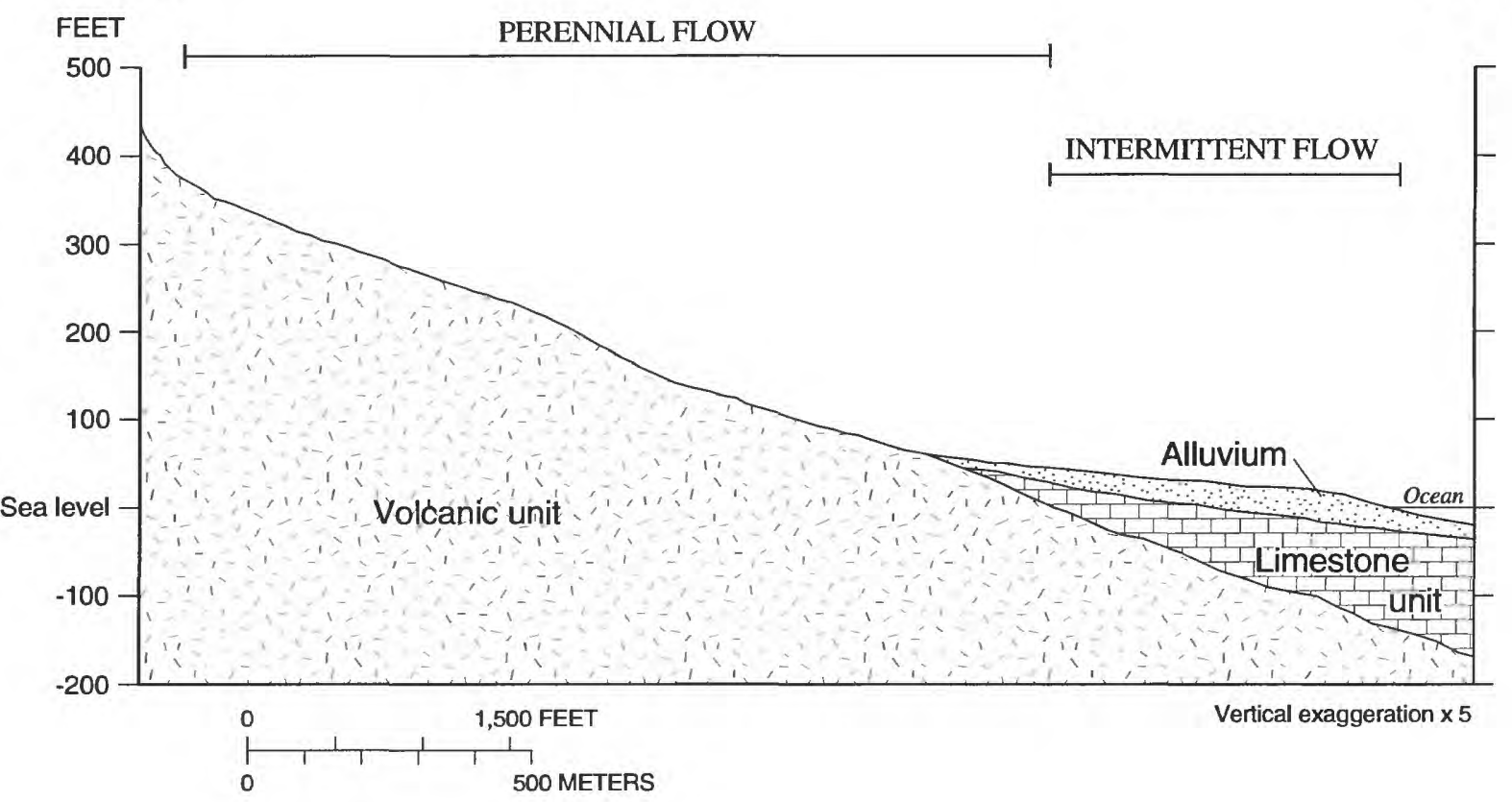

B

WEST

EAST

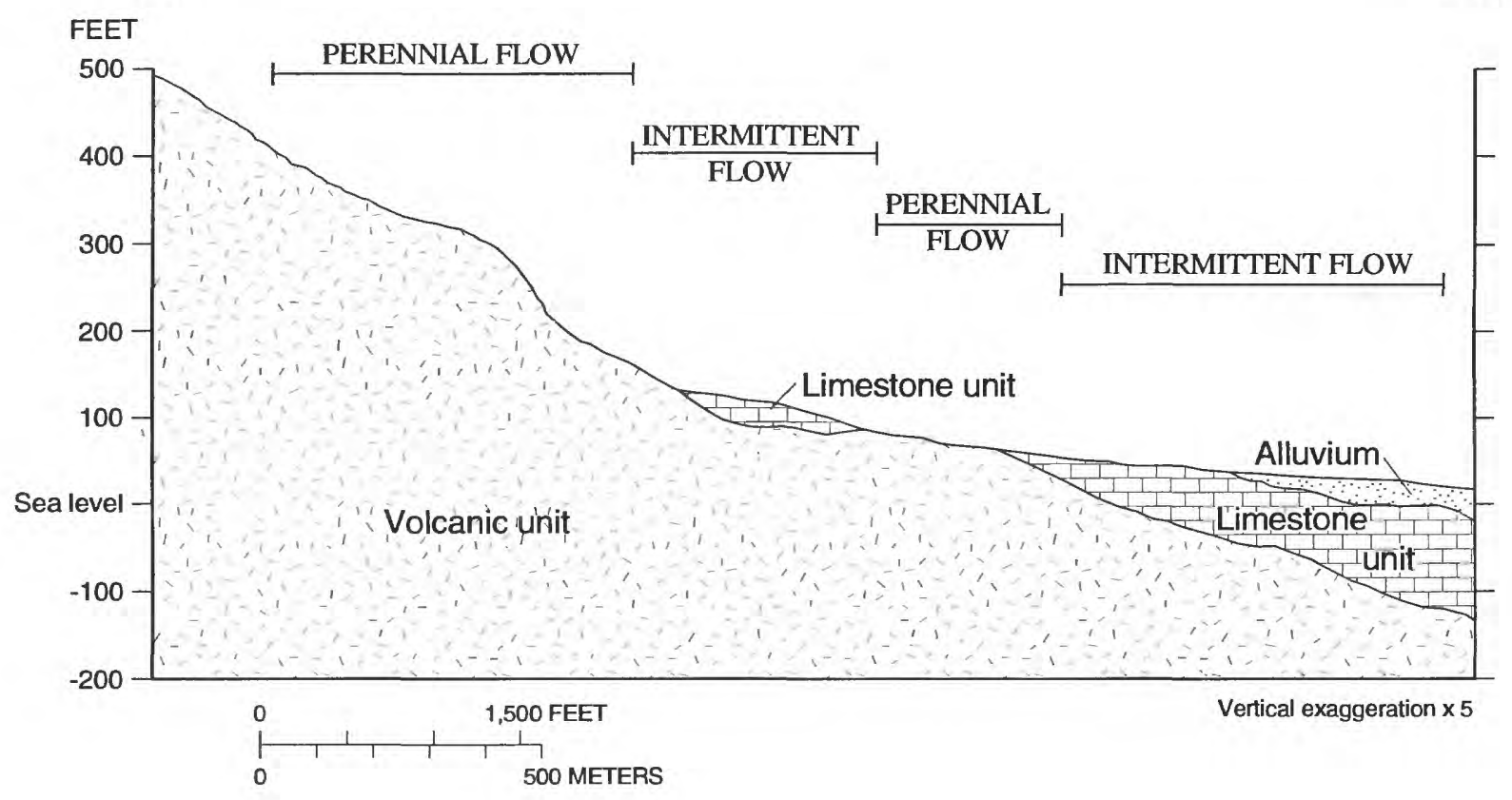

Figure 7. Profile and geology along channel of the; $\boldsymbol{A}$, Middle Fork and; $\boldsymbol{B}$, North Fork of Talufofo Stream, Saipan. 
trenched in limestone. The thickness of channel-filling alluvium increased markedly downstream from this elevation because sediment was deposited when the stream lost carrying capacity as flow diminished.

Base flow in the North Fork was continuous from its origin at the spring at $430 \mathrm{ft}$ elevation, but diminished to zero at about $150 \mathrm{ft}$ elevation at the time the seepage runs were made (fig. 2). The North Fork channel was dry between $150 \mathrm{ft}$ and $90 \mathrm{ft}$ elevation, but water seeped out of the ground and surface flow resumed below $90 \mathrm{ft}$ elevation. The flow continued downstream to about $60 \mathrm{ft}$ elevation, where it ceased in small pools in limestone. No surface flow occurred below this point in the North Fork channel.

The discontinuity of base flow in the North Fork appears to correspond approximately to the occurrence of limestone between elevations of $120 \mathrm{ft}$ and $80 \mathrm{ft}$ along the North Fork channel, and again at $60 \mathrm{ft}$ elevation (fig. 7). The base flow originating at the headwaters of the North Fork flowed over the volcanic unit, but the stream lost all of its water to seepage when it approached the outcrop of limestone at $120 \mathrm{ft}$. Farther downstream, where the North Fork channel again cuts down into the volcanic unit, surface flow reappeared and continued downstream until it encountered limestone at an elevation of $60 \mathrm{ft}$. This pattern of streamflow was unlike that in the Middle and South Forks, where base flow was continuous along the entire reach of the main channel until limestone and alluvium formed the channel at the $30 \mathrm{ft}$ elevation.

The combination of rock types and structures appear to influence where Talufofo Stream gained and lost water. Nearly all of the flow during the period of field study in Talufofo Stream occurred where the channel is cut into the volcanic unit (figs. 3 and 7). Where the stream channel cut into limestone and alluvium, water seeped into the ground. Thus, during the 1990 dry season, the lower reaches of the stream were dry.

All of the dry-weather springs observed during this study discharged from the volcanic unit a few feet below the contact with the Tagpochau Limestone. The proximity of the springs to the limestone indicate that the spring water may be coming from storage in the limestones as well as the volcanic rocks. Calcareous deposits up to a few tenths of inches thick on rocks and roots in the channel indicate that water seeping from the ground in this area has a high concentration of dissolved calcium.
The location of the springs may indicate where the ground-water table intersects the land surface, but the elevations of the Talufofo seeps were estimated from contours on a topographic map and are imprecise. At the time of this study, the springs discharged between $400 \mathrm{ft}$ and $490 \mathrm{ft}$ elevation. Water-table elevations in the limestone above the Talufofo Stream Basin were near the same elevation as the springs. A well drilled in the basin (well 43, fig. 3) had a static water elevation of 530 $\mathrm{ft}$ in 1945 (van der Brug, 1985) and two wells located just above the basin (wells 12-01X and 12-02X, fig. 3) had static water levels of about $420 \mathrm{ft}$ in 1990 (J. P. Hoffmann, USGS, oral commun., 1990).

\section{WATER CHEMISTRY}

Water temperature, $\mathrm{pH}$, and specific conductance were measured at most of the seepage-run sites on Talufofo Stream (table 11). Six water samples were collected near the headwaters and near the confluence of each fork on Talufofo Stream. The samples were filtered through a membrane with 0.45 micron opening to remove suspended solids, and stored in $250 \mathrm{~mL}$ plastic bottles until they arrived at the USGS laboratory for analysis. The water samples were analyzed for dissolved $\mathrm{NO}^{2-}, \mathrm{NO}_{3}{ }^{2-}, \mathrm{Ca}^{2+}, \mathrm{Mg}^{2+}, \mathrm{Na}^{+}, \mathrm{K}^{+}, \mathrm{Cl}^{+}, \mathrm{SO}_{4}{ }^{2-}$, $\mathrm{F}^{-}, \mathrm{SiO}_{2}{ }^{2-}, \mathrm{Fe}^{2+}$, and $\mathrm{Mn}^{2+}$. Samples for cation analysis were stabilized with nitric acid to prevent sorption and precipitation of dissolved metals during transport. Samples for anion and alkalinity analysis were left untreated.

A sample for trace-metal analysis was collected from the lower reaches of the Middle Fork. The sample was not filtered; therefore, the reported concentrations include both suspended and dissolved material, but the water was not visibly turbid at the time of collection. The sample was stabilized with nitric acid. A sample split taken for mercury analysis was also treated with potassium chromate. The water sample was analyzed for arsenic, barium, beryllium, cadmium, chromium, cobalt, copper, iron, lead, manganese, molybdenum, nickel, silver, zinc, aluminum, lithium, selenium and mercury. 
Table 11. Summary of field water-quality measurements and water sampling, Talufofo Stream, Saipan

[See fig. 2 for site locations; --, data not collected; ${ }^{\circ} \mathrm{C}$, degrees Celsius]

\begin{tabular}{|c|c|c|c|c|c|}
\hline Site & Date & $\begin{array}{c}\text { Temperature } \\
\left({ }^{\circ} \mathrm{C}\right)\end{array}$ & $\begin{array}{l}\text { Specific conductance } \\
\text { (microsiemens per } \\
\text { centimeter at } 25^{\circ} \mathrm{C} \text { ) }\end{array}$ & pH & $\begin{array}{c}\text { Sample } \\
\text { collected for lab analysis }\end{array}$ \\
\hline $\mathrm{S} 2$ & $6-13-90$ & 29.0 & - & 7.20 & Major ions \\
\hline S5 & $6-13-90$ & 29.0 & 400 & 7.75 & \\
\hline S4 & $6-13-90$ & 26.0 & 420 & 8.82 & \\
\hline S5 & $6-13-90$ & 25.0 & 460 & 7.59 & \\
\hline S6 & $6-13-90$ & - & 450 & 7.63 & Major ions \\
\hline M1 & $6-08-90$ & - & - & -- & Major ions \\
\hline M3 & $6-08-90$ & 26.5 & 322 & -- & \\
\hline M4 & $6-11-90$ & 26.5 & 350 & -- & \\
\hline M5 & $6-11-90$ & 27.5 & - & - & \\
\hline M6 & $6-11-90$ & 27.5 & - & -- & \\
\hline M9 & $6-12-90$ & 26.5 & 360 & 7.75 & Major ions, trace metals \\
\hline N3 & $6-12-90$ & 29.0 & 740 & 7.10 & Major ions \\
\hline N4 & $6-12-90$ & 27.0 & 557 & 7.60 & Major ions \\
\hline
\end{tabular}

\section{Major Dissolved lons}

The six water samples from Talufofo Stream share several dissolved-ion characteristics (table 12). In all samples, $\mathrm{Ca}^{2+}$ accounts for the largest proportion of the mass of dissolved cations, followed by, in order of decreasing proportion, $\mathrm{Na}^{+}, \mathrm{Mg}^{2+}$, and $\mathrm{K}^{+}$. The anions include all negatively charged dissolved ions such as $\mathrm{Cl}^{-}$, $\mathrm{SO}_{4}{ }^{2-}, \mathrm{F}^{-}, \mathrm{NO}^{2-}$ and $\mathrm{NO}^{3-}$. The alkalinity of water is normally grouped with the anions because in most natural waters, alkalinity is produced by the presence of $\mathrm{HCO}^{3-}$ and $\mathrm{CO}_{3}{ }^{2-}(\mathrm{Hem}, 1985)$. Among the anions in the Talufofo Stream samples, the alkalinity accounts for the greatest proportion of dissolved anion mass, followed by $\mathrm{Cl}^{-}$and $\mathrm{SO}_{4}{ }^{2-}$. $\mathrm{SiO}_{2}$ is also a major dissolved constituent but is considered neither a cation nor anion
(Hem, 1985). Other elements, including $\mathrm{NO}^{2-}, \mathrm{NO}^{3-}$, $\mathrm{Fe}^{2+}$, and $\mathrm{Mn}^{2+}$, although part of the major ion analysis, are present only in minor concentrations in water from Talufofo Stream.

Units of milligrams per liter are a means of studying concentrations of individual ionic species, but milliequivalent units, which give the concentration of the unbalanced charge made available by the presence of an ionic species in solution, are required for charge-balance calculations. When concentration is expressed in milliequivalents, the total concentration of dissolved cations should balance the total dissolved anions. The milliequivalent unit is also useful in determining which solids may have been dissolved to give the ions found in the water samples. Effects of channel and aquifer lithology may then be discussed.

Table 12: Concentrations of major dissolved ions, Talufofo Stream, Saipan

[See fig. 2 for site locations; concentrations in milligrams per liter; $\mathrm{NO}_{2}$ and $\mathrm{NO}_{3}$ concentration reported as $\mathrm{N}$; Alk, alkalinity as $\mathrm{CaCO}$; $<$, less than]

\begin{tabular}{|c|c|c|c|c|c|c|c|c|c|c|c|c|}
\hline \multirow[b]{2}{*}{ Site } & \multicolumn{12}{|c|}{ Concentrations, in mllitigrams per liter } \\
\hline & $\mathrm{Ca}$ & $\mathbf{M g}$ & $\mathrm{Na}$ & $\mathbf{K}$ & $\mathrm{Fe}$ & Mn & Cl & $\mathrm{SO}_{4}$ & $\mathbf{F}$ & $\mathrm{SiO}_{2}$ & Alk & $\mathrm{NO}_{2}$ and $\mathrm{NO}_{3}$ \\
\hline $\mathbf{S} 2$ & 62 & 12 & 48 & 0.60 & 0.028 & 0.086 & 70 & 14 & 0.20 & 40 & 198 & $<0.10$ \\
\hline S6 & 42 & 6.8 & 39 & 1.60 & 0.009 & 0.013 & 50 & 7.0 & $<0.10$ & 44 & 143 & $<0.10$ \\
\hline M3 & 35 & 6.4 & 28 & 1.20 & 0.023 & 0.004 & 33 & 3.4 & $<0.10$ & 42 & 128 & $<0.10$ \\
\hline M9 & 38 & 6.8 & 30 & 1.60 & 0.018 & 0.002 & 37 & 3.9 & $<0.10$ & 42 & 136 & $<0.10$ \\
\hline N3 & 98 & 9.9 & 45 & 1.30 & 0.009 & 0.025 & 66 & 5.0 & 0.20 & 26 & 292 & $<0.10$ \\
\hline N4 & 92 & 10 & 44 & 1.40 & 0.023 & 0.004 & 66 & 5.0 & 0.20 & 23 & 252 & $<0.10$ \\
\hline
\end{tabular}


Table 13. Concentration, in milliequivalents per liter, of major dissolved ions, Talufofo Stream, Saipan [Alkalinity is anionic charge due to $\mathrm{HCO}^{3-}$ and $\mathrm{CO}_{3}{ }^{2}$ ]

\begin{tabular}{cccccccc}
\hline & \multicolumn{5}{c}{ Concentration, in milliequivalents per liter } \\
\cline { 2 - 8 } Site & $\mathbf{C a}^{2+}$ & $\mathbf{M g}^{2+}$ & $\mathbf{N a}^{+}$ & $\mathbf{K}^{+}$ & \multicolumn{1}{c}{$\mathbf{C l}^{-}$} & $\mathbf{S O}_{4}{ }^{2-}$ & Alkalinity $^{-}$ \\
\hline S2 & 3.1 & 0.99 & 2.1 & 0.015 & 2.0 & 0.29 & 4.0 \\
S6 & 2.1 & 0.56 & 1.7 & 0.041 & 1.4 & 0.15 & 2.9 \\
M3 & 1.7 & 0.53 & 1.2 & 0.031 & 0.93 & 0.071 & 2.6 \\
M9 & 1.9 & 0.56 & 1.3 & 0.041 & 1.0 & 0.081 & 2.7 \\
N3 & 4.9 & 0.82 & 2.0 & 0.033 & 1.9 & 0.10 & 5.8 \\
N4 & 4.6 & 0.82 & 1.9 & 0.036 & 1.9 & 0.10 & 5.0 \\
\hline
\end{tabular}

Units of milliequivalents per liter (meq/L) are obtained by dividing the concentration, in milligrams per liter, of the dissolved ion by the atomic weight of the ion and multiplying by the charge of the ion. Concentrations of the major dissolved ions, excluding $\mathrm{NO}^{2-}$, $\mathrm{NO}^{3-}, \mathrm{F}^{+}, \mathrm{Fe}^{2+}$, and $\mathrm{Mn}^{2+}$, whose concentrations are small, and $\mathrm{SiO}_{2}$ which has no charge, are listed in table 13. In all water samples from Talufofo Stream, $\mathrm{Ca}^{2+}$ accounts for most of the cationic charge and $\mathrm{HCO}_{3}{ }^{-}$and $\mathrm{CO}_{3}{ }^{2-}$ account for most of the anionic charge (fig. 8). High proportions of these dissolved constituents can be attributed to solution of minerals in the limestone aquifers from which the low-stage streamflow in the Talufofo basin originates. Dissolution of limestone, composed predominantly of the minerals calcite and aragonite both of which have the formula $\mathrm{CaCO}_{3}$, yields $\mathrm{Ca}^{2+}$ cations and $\mathrm{CO}_{3}{ }^{2-}$ anions.

The equivalent concentrations of $\mathrm{Mg}^{2+}$ and $\mathrm{SO}_{4}{ }^{2-}$ may also be traced to solution of minerals in the limestone. Some marine calcites may originally contain as much as 5 percent $\mathrm{Mg}^{2+}$ by weight (Clark and Wheeler, 1922). During diagenesis, magnesium-rich calcite tends to be selectively dissolved over low-magnesium calcite (Bathurst, 1975). Gypsum $\left(\mathrm{CaSO}_{4} \cdot \mathrm{H}_{2} \mathrm{O}\right)$, which also occurs in marine sediments, may be contributing to the proportions of $\mathrm{Ca}^{2+}$ and $\mathrm{SO}_{4}{ }^{2-}$ in the stream water. The $\mathrm{SO}_{4}{ }^{2-}$ anion is also a major dissolved constituent of seawater (Dietrich and others, 1980) and may be introduced to stream water through sea spray.

Sodium accounts for the second largest proportion of charge due to the presence of dissolved cations in water from Talufofo Stream, and $\mathrm{Cl}^{-}$accounts for the second largest proportion of anionic charge. The milliequivalent concentrations of sodium and chloride ions are nearly equal, which suggests that the source of these ions is sea salt. Other sources of sodium and chloride ions such as the weathering of volcanic rock yield only small amounts of these elements and therefore cannot account for the concentrations found in the Talufofo stream water. Sea salt may enter stream water from sea spray through rainfall or by leaching of salt trapped in sedimentary rocks such as limestones (Hem, 1985).

The concentration of $\mathrm{K}^{+}$in Talufofo Stream ranged from $0.6 \mathrm{mg} / \mathrm{L}$ to $1.6 \mathrm{mg} / \mathrm{L}$. In all forks, $\mathrm{K}^{+}$concentration increased from upstream to downstream sampling sites (table 12 and 13, fig. 8). Potassium is a major constituent of sea salt (Dietrich and others, 1980), and some of the potassium may have entered Talufofo Stream water from sea spray. Decaying vegetation may also introduce $\mathrm{K}^{+}$to the stream. Potassium is an important element in biological processes and becomes available when organic matter decays (Hem, 1985). Potassium is present in igneous minerals such as feldspars, but weathering of these minerals yields little $\mathrm{K}^{+}$to stream water because the $\mathrm{K}^{+}$tends to remain locked in stable clay minerals (Hem, 1985).

In summary, the concentrations of dissolved constituents in the base flow at selected sites on Talufofo Stream reflect the base flow's origin as spring discharge from a carbonate aquifer, and that the surface flow occurs in a heavily forested basin near the ocean.

\section{Trace Metal Analysis}

The sample analyzed for trace metals was collected at site M9 (fig. 2), where one of the major-ion samples was also collected. When comparing the results of trace-metal (table 14) and major-ion analyses, it must be stressed that the results of the trace-metal analysis reflect chemistries of both suspended and dissolved solids, whereas results of the major-ion analysis show only the dissolved concentrations. Comparison of the two analyses for this site show that the total iron content 

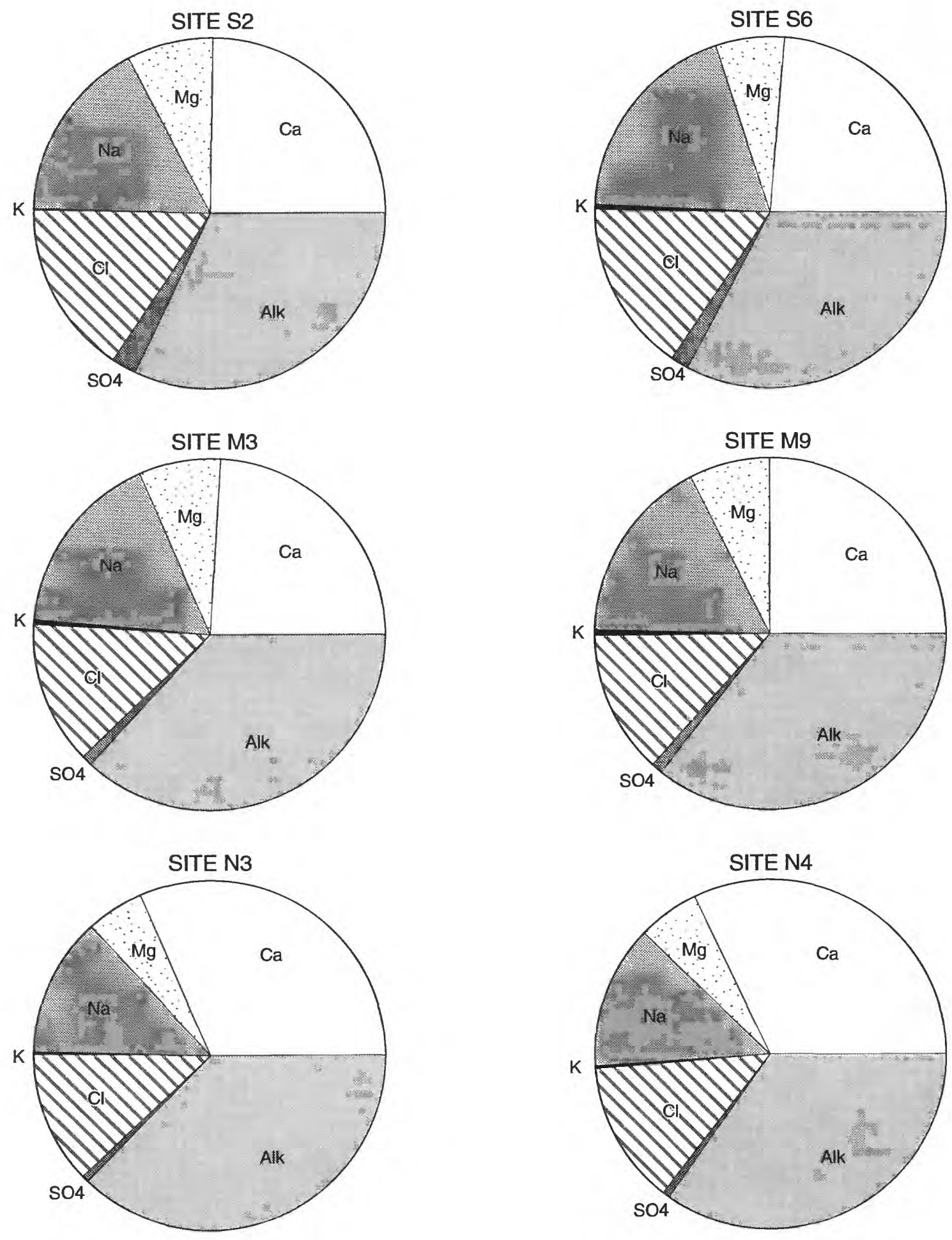

Figure 8. Proportions, based on millequivalent units, of major dissolved ions in water sampled in June 1990 from Talufofo Stream, Saipan (see fig. 2 for site locations). 
Table 14. Dissolved and suspended trace metals in water from site M9, Middle Fork, Talufofo Stream, Saipan

[*, below detection limit of 1 microgram per liter, see fig. 2 for location of site M9]

\begin{tabular}{lc}
\hline \multicolumn{1}{c}{ Metal } & $\begin{array}{c}\text { Concentration, in } \\
\text { microgram per liter }\end{array}$ \\
\hline Arsenic & $*$ \\
Barium & $*$ \\
Beryllium & $*$ \\
Cadmium & $*$ \\
Chromium & 1 \\
Cobalt & $*$ \\
Copper & 2 \\
Iron & 390 \\
Lead & $*$ \\
Manganese & 20 \\
Molybdenum & $*$ \\
Nickel & $*$ \\
Silver & $*$ \\
Zinc & $*$ \\
Aluminum & $*$ \\
Lithium & $*$ \\
Selenium & $*$ \\
Mercury & $*$ \\
\hline &
\end{tabular}

(dissolved and suspended) is about 22 times higher than the dissolved iron and total manganese is 10 times higher than dissolved manganese. This indicates that most of the iron and manganese in the water exists as suspended solids rather than dissolved ions, a distribution that is explained by the chemical behavior of these elements. Both iron and manganese tend to form solid precipitates in oxidizing environments such as flowing surface water (Krauskopf, 1979). They are also taken into the tissues of plants and animals (Hem, 1985). Talufofo Stream water also contained low levels of copper (2 $\mu \mathrm{g} / \mathrm{L})$ and chromium $(1 \mu \mathrm{g} / \mathrm{L})$, but the sources of theses constituents in Talufofo Stream is unknown. Copper does occur as a minor element in intermediate and felsic volcanic rocks (Krauskopf, 1979). Concentrations of all other metals in the trace-metal analysis were below detection limit of $1 \mu \mathrm{g} / \mathrm{L}$.

\section{POSSIBLE EFFECTS OF GROUND- WATER PUMPAGE ON STREAMFLOW}

The seepage measurements and water chemistry indicate that the spring discharge in Talufofo Stream is in hydraulic connection with ground water in the limestones near the headwaters of the basin. The data offer two independent lines of evidence pointing to this conclusion: (1) springs feeding the base flow discharged near the base of the limestones at the contact with the underlying volcanic rocks and elevations of springs are very close to water levels in wells in the limestones, and (2) stream water chemistry indicates substantial contact with limestones. Because of this connection, artificial stresses placed on the ground-water body, such as pumping from wells, may affect flow in the Talufofo Stream Basin although the magnitude of the effect cannot be predicted from the existing data.

Under natural conditions, recharge of ground water from infiltration of rainfall is balanced by groundwater discharge at the coast or at springs such as in Talufofo Stream (fig. 9). If the balance is artificially disturbed by a pumped well, the shape and size of the ground-water body will change until a new balance is established. Such a balance can only be reached if the volume of water that is pumped at the well is compensated by a reduction of natural discharge at a spring or at the coast. (fig. 9). The pumping from wells in the limestones within or above the Talufofo Stream Basin may therefore reduce the springflow to the basin. The reduction in discharge will be most apparent during the dry season.

\section{CONCLUSIONS}

Peak streamflows and long-term average flow are higher at the South Fork gaging station than at the Middle Fork gaging station because the drainage area of the South Fork gaging station is larger. However, persistent base flow from ground-water discharge during dry weather is greater in the Middle Fork gaging station.

The sum of the average flows at the Middle Fork and South Fork gaging stations, plus an estimate of the average flow at a point in the lower reaches of the North Fork is about $2.96 \mathrm{ft}^{3} / \mathrm{s}$, or $1.91 \mathrm{Mgal} / \mathrm{d}$. This average includes flows from wet and dry seasons through several years of record, and is an estimate of the upper limit of long-term water resources available from Talufofo 
A

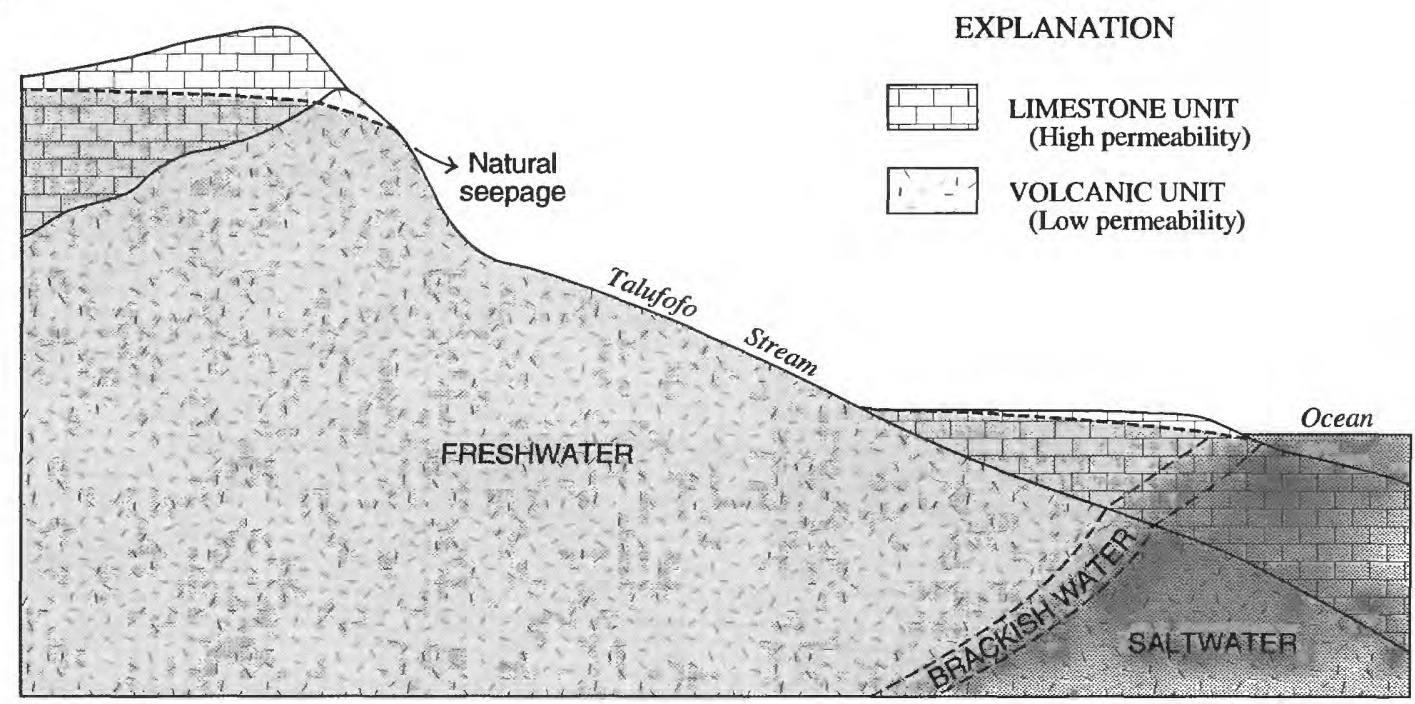

B Discharge

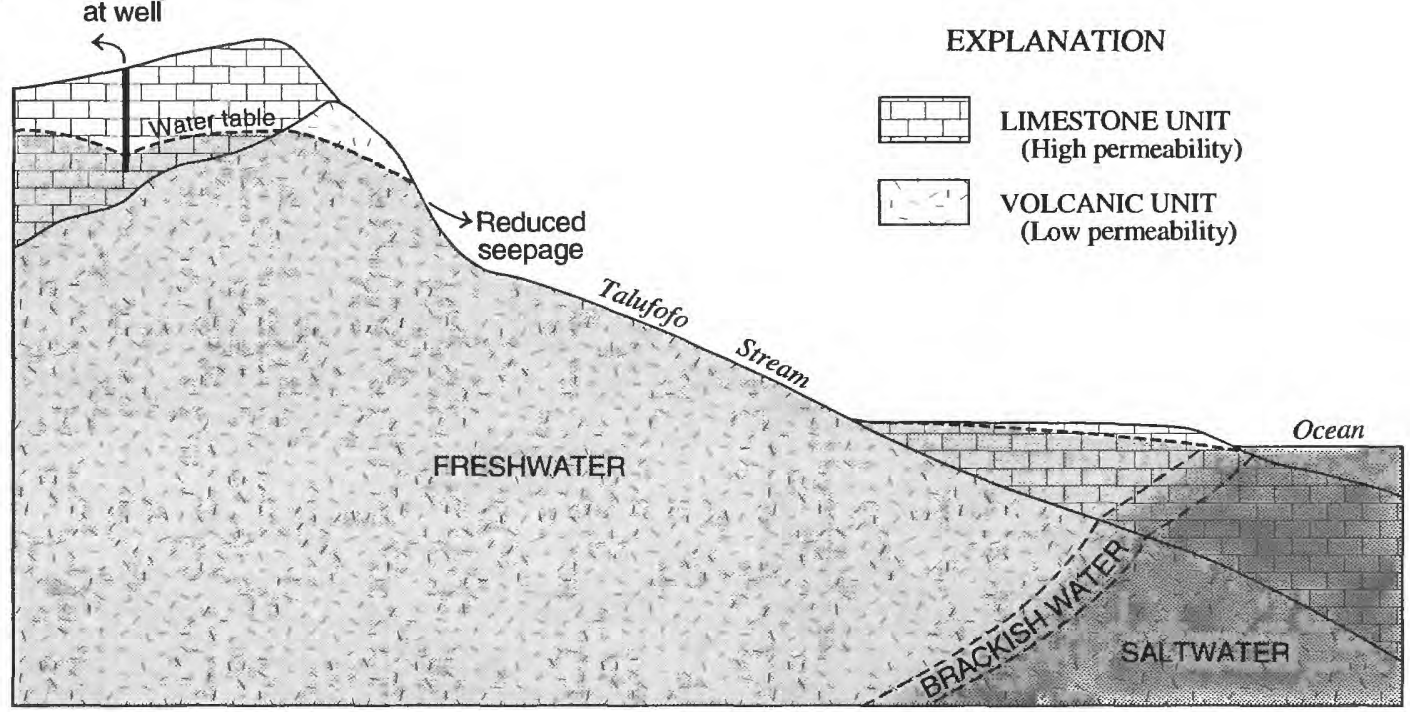

Figure 9. Schematic diagram of possible relation between ground water and stream flow in the Talufofo Stream Basin, Saipan; $\boldsymbol{A}$, before and; $\boldsymbol{B}$, after pumping from wells. 
Stream. The actual amount available from the stream is probably less because of evaporation, leaks, and induced infiltration, and is also constrained by reservoir design limitations.

Base flow in Talufofo Stream originates from springs near the contact between volcanic rocks and overlying limestones at the headwaters of the basin. The stream is intermittent along some reaches, but is perennial along others. The occurrence of perennial flow is directly related to geology. Flow is perennial where volcanic rocks are exposed at the surface and is intermittent where limestone is exposed at the surface. Surface flow over limestones cannot be maintained during dry periods because the permeability of limestones is high. The high permeability of limestones is also an important consideration when sites for reservoirs are chosen.

Water samples collected from Talufofo Stream during the dry season are high in calcium, which reflects the origin of dry-weather flow from a limestone aquifer. Other dissolved elements may also be explained by the association with a limestone aquifer and a heavily forested basin near the ocean.

The seepage and water chemistry data indicate that the source of base flow in the Talufofo Stream Basin is a limestone aquifer at the headwaters of the stream. The base flow is therefore subject to stresses placed on the nearby limestone ground-water system. Pumping from wells in the limestones at the headwaters of Talufofo Stream may decrease dry-weather flow in the stream.

\section{REFERENCES CITED}

Banks, N.G., Koyanagi, R.Y., Sinton, J.M., and Honma, K.T., 1984, The eruption of Mount Pagan Volcano, Mariana Islands, May 15, 1981: Journal of Volcanology and Geothermal Research, v. 22, p. 225-269.

Bathurst, R., 1975, Carbonate sediments and their diagenesis: 2nd ed., Amsterdam, Elsevier, 658 p.

Chinn, S.S., Tateishi, G. A., and Yee, J.S., 1987, Water resources data Hawaii and other Pacific areas water year 1987, volume 2. Guam, Northern Mariana Islands, Federated States of Micronesia, Palau and American Samoa: U.S. Geological Survey Water Data Report HI-87-2

Chow, 1964a, Streamflow: in Chow, V.T. (ed.), Handbook of applied hydrology: New York, McGraw-Hill, p. 14-1 to 8-54.

Chow, V.T., 1964b, Statistical and probability analysis: in Chow, V.T. (ed.), Handbook of applied hydrology: New York, McGraw-Hill, p. 8-1 to 8-42.
Cloud, P.E. Jr., Schmidt, R.G., and Burke, H.W., 1956, Geology of Saipan, Mariana Islands, Part 1. General Geology: U.S. Geological Survey Professional Paper 280-A, 126. p.

Clarke F. W. and Wheeler, W. C., 1922, The inorganic constituents of marine invertebrates: U.S. Geological Survey Professional Paper 124, p. 1-62.

Davis, D.A., 1958, Water resources: in Military geology of Saipan, Mariana Islands, Chief of Engineers, U.S. Army, v. 2, 96 p.

Dietrich, G., Kalle, K., Krauss, K., and Siedler, G., 1980, General oceanography, an introduction: New York, John Wiley and Sons, $626 \mathrm{p}$.

Hem, J. D., 1985, Study and interpretation of the chemical constituents of natural water: 3 rd ed., U.S. Geological Survey Water Supply Paper 2254, 264 p.

Karig, D.E., 1971, Structural history of the Mariana arc system: Geological Society of America Bulletin, v. 82, p. 323-344.

Krauskopf, K.B., 1979, Introduction to geochemistry, 2nd ed.: New York, McGraw Hill, 617 p.

Langbein, W.B., and Iseri, K.T., 1960, General introduction and hydrologic definitions: Manual of Hydrology, Part 1, General Surface-Water Techniques, U.S. Geological Survey Water Supply Paper 1541-A, 29 p.

Linsley, R.K. and Franzini, J.B, 1972, Water resources engineering, 2nd ed: New York, McGraw-Hill, 690 p.

Rantz, S.E. and others, 1982, Measurement and computation of streamflow: volume 2, Measurement of stage and discharge: U.S. Geological Survey Water-Supply Paper $2175,284 \mathrm{p}$.

Ritter, E.J. and Engstrom, Le Roy, 1964, Hydrology of flow control, Part III, Reservoir regulation: in Chow, V.T.(ed.), Handbook of applied hydrology: New York, McGraw-Hill, p. 25-60 to 25-97.

Tayama, R., 1938, Geomorphology, geology and coral reefs of Saipan Island: Bulletin of the Tropical Industry Institute, Palau, South Sea Islands, Japan, No. 1, 62 p.

Thomas, D.M. and Benson, M.A., 1970, Generalization of streamflow characteristics from drainage-basin characteristics: U.S. Geological Survey Water-Supply Paper $1975,55 \mathrm{p}$.

van der Brug, Otto, 1985, Compilation of water resources development and hydrologic data of Saipan, Mariana Islands: U.S. Geological Survey Water-Resources Investigations Report 84-4121, 578 p. 